\title{
Visual Landmark Information Gains Control of the Head Direction Signal at the Lateral Mammillary Nuclei
}

\author{
Ryan M. Yoder, James R. Peck, and ㅈeffrey S. Taube \\ Department of Psychological and Brain Sciences, Center for Cognitive Neuroscience, Dartmouth College, Hanover, New Hampshire 03755
}

\begin{abstract}
The neural representation of directional heading is conveyed by head direction (HD) cells located in an ascending circuit that includes projections from the lateral mammillary nuclei (LMN) to the anterodorsal thalamus (ADN) to the postsubiculum (PoS). The PoS provides return projections to LMN and ADN and is responsible for the landmark control of HD cells in ADN. However, the functional role of the PoS projection to LMN has not been tested. The present study recorded HD cells from LMN after bilateral PoS lesions to determine whether the PoS provides landmark control to LMN HD cells. After the lesion and implantation of electrodes, HD cell activity was recorded while rats navigated within a cylindrical arena containing a single visual landmark or while they navigated between familiar and novel arenas of a dual-chamber apparatus. PoS lesions disrupted the landmark control of HD cells and also disrupted the stability of the preferred firing direction of the cells in darkness. Furthermore, PoS lesions impaired the stable HD cell representation maintained by path integration mechanisms when the rat walked between familiar and novel arenas. These results suggest that visual information first gains control of the HD cell signal in the LMN, presumably via the direct PoS $\rightarrow$ LMN projection. This visual landmark information then controls HD cells throughout the HD cell circuit.
\end{abstract}

Key words: landmark; mammillary; navigation; rat; spatial orientation; visual

\section{Introduction}

Most mammals are able to reliably perceive their momentary directional heading relative to the environment. In rodents, this directional perception is thought to be encoded by head direction (HD) cells, which are located throughout the limbic system (for review, see Taube, 2007). This HD cell signal appears to be generated from self-movement information that arrives from the vestibular system, but proprioceptive and/or motor efference cues also play a major role in updating the signal during movement (Taube and Burton, 1995; Blair et al., 1997; Stackman and Taube, 1997; Frohardt et al., 2006; Yoder et al., 2011a). Although these idiothetic cues are important for generating and updating the signal, visual landmarks dominantly control the preferred firing direction of the HD cell when these cues are available (Goodridge and Taube, 1995; Zugaro et al., 2003). The neural circuit responsible for providing this "landmark control" to the HD signal is not fully understood but is particularly important for our understanding of navigation and spatial learning.

HD signal generation appears to occur within the reciprocal connections between the dorsal tegmental nuclei and the lateral mammillary nuclei (LMN), in which vestibular, motor efference

\footnotetext{
Received April 1, 2014; revised Nov. 13, 2014; accepted Nov. 18, 2014.

Author contributions: R.M.Y., J.R.P., and J.S.T. designed research; R.M.Y. and J.R.P. performed research; R.M.Y., J.R.P., and J.S.T. analyzed data; R.M.Y., J.R.P., and J.S.T. wrote the paper.

This work was supported National Institutes of Health Grants NS053907 (J.S.T.) and DC008481 (R.M.Y.)

Correspondence should be addressed to Jeffrey S. Taube, Department of Psychological and Brain Sciences, 6207 Moore Hall, Dartmouth College, Hanover, NH 03755. E-mail: Jeffrey.S.Taube@Dartmouth.edu.

R.M. Yoder's present address: Department of Psychology, Indiana University-Purdue University Fort Wayne, Neff Hall 380C, Fort Wayne, IN 46805.

DOI:10.1523/JNEUROSCI.1418-14.2015

Copyright $\odot 2015$ the authors $\quad 0270-6474 / 15 / 351354-14 \$ 15.00 / 0$
}

copy, and optic flow information arrive from the medial vestibular nucleus, nucleus prepositus hypoglossi, supragenual nucleus, and paragigantocellular reticularis nucleus (Taube and Bassett, 2003; Song and Wang, 2005; Biazoli et al., 2006). From the LMN, the HD signal is projected bilaterally to the anterodorsal thalamus (ADN), which projects to various cortical areas, including the postsubiculum (PoS), retrosplenial cortex, and medial entorhinal cortex (MEC; Shibata, 1993; Van Groen and Wyss, 1995; Blair et al., 1999). This ascending HD cell circuit appears to provide idiothetic information to higher brain structures, which may use this information to guide navigation when necessary.

Idiothetic cues can guide navigation, but most mammals (and many birds, fish, and other invertebrates) rely on visual landmarks when they are perceived as reliable indicators of position (Gallistel, 1990). Accordingly, visual information dominantly controls navigation and HD cells when landmarks are perceived as stable (Goodridge and Taube, 1995, Knierim et al., 1995), suggesting that a descending projection may provide visual input to HD cells. This visual input presumably originates in area 17, which may influence the HD signal via a direct projection to the PoS (Vogt and Miller, 1983). The PoS projects directly to ADN, and removal of the PoS disrupts landmark control of ADN HD cells (Goodridge and Taube, 1997), suggesting that the PoS may influence $\mathrm{ADN}$ HD cells via the direct $\mathrm{PoS} \rightarrow \mathrm{ADN}$ projection (van Groen and Wyss, 1990a). However, visual information also controls the HD signal upstream from ADN, in the LMN (Blair et al., 1998; Stackman and Taube, 1998), and this visual input may arrive via the unilateral PoS $\rightarrow$ LMN projection (Shibata, 1989; van Groen and Wyss, 1990a; Yoder and Taube, 2011b). To test this hypothesis, we evaluated the response of LMN HD cells to 
Table 1. Stereotaxic coordinates for NMDA injection into the POS and overlying cortex

\begin{tabular}{lllll}
\hline Site & $\begin{array}{l}\text { Anteroposterior } \\
(\mathrm{mm})\end{array}$ & $\begin{array}{l}\text { Mediolateral } \\
(\mathrm{mm})\end{array}$ & $\begin{array}{l}\text { Dorsoventral } \\
(\mathrm{mm})\end{array}$ & $\begin{array}{l}\text { Volume/ } \\
\text { site }(\mu \mathrm{l})\end{array}$ \\
\hline PoS & -6.7 & 2.7 & -4.0 & 0.3 \\
& -6.8 & 2.8 & -3.5 & 0.3 \\
& -7.3 & 2.8 & -3.5 & 0.3 \\
& -7.3 & 3.5 & -4.2 & 0.3 \\
& -7.6 & 3.2 & -4.2 & 0.3 \\
Cortex & -6.7 & 2.7 & -2.5 & 0.2 \\
& -6.8 & 2.8 & -2.5 & 0.2 \\
& -7.3 & 2.8 & -2.5 & 0.2 \\
& -7.3 & 3.5 & -2.5 & 0.2 \\
& -7.6 & 3.2 & -2.5 & 0.2 \\
\hline
\end{tabular}

visual cue manipulations after bilateral excitotoxic lesions of the PoS. To determine whether the PoS also contributes to path integration, we evaluated the stability of HD cells during darkness and in the dual-chamber apparatus where animals walk between familiar and novel arenas.

\section{Materials and Methods}

\section{Subjects and training}

All experimental procedures were approved by the Dartmouth College Institutional Animal Care and Use Committee and conformed to the standards outlined in the National Institutes of Health Guide for the Care and Use of Laboratory Animals. Female Long-Evans hooded rats were used ( $n=19$; age, 3-12 months; weight, 255-414 $\mathrm{g}$ at the time of surgery). All rats were pair-housed preoperatively and housed individually postoperatively in the same colony room with a $12 \mathrm{~h}$ light/dark cycle.

\section{Electrodes}

A movable multielectrode microdrive was constructed as described previously (Kubie, 1984). Each microdrive consisted of ten $25-\mu \mathrm{m}$ insulated nichrome wires (California Fine Wire) encased by a 26 gauge stainless steel cannula. Each wire contacted one gold pin of a modified 11-pin Augat connector. Dental acrylic was used to encase the cannula, wires, and connector and to hold the heads of three drive screws. The finished electrode drive provided connections for 10 recording electrodes (tip impedance, $\sim 2 \mathrm{M} \Omega$ ) and one ground connection. After construction, the tips of the drive screws were threaded into custom-built plastic cuffs, which would later be cemented to the skull. These cuffs provided a fixed base into which the screws were advanced to lower the electrodes into the brain. Before surgical implantation, the electrode bundle was sterilized and coated (except for the tips) with polyethylene glycol (Carbo wax) to provide stability to the electrode wires as they were positioned in the brain.

\section{Surgery}

Rats were anesthetized with sodium pentobarbital (Nembutal; $50 \mathrm{mg} / \mathrm{kg}$ body weight) and positioned in a stereotaxic apparatus (David Kopf Instruments) with bregma and lambda on the same plane. Some rats received only electrode implants $(n=6)$, whereas other rats received excitotoxic injections of $100 \mathrm{~mm}$ NMDA into the PoS $(n=11)$. Because excitotoxic injections produced some damage to visual and retrosplenial cortical areas overlying the PoS, two additional animals received excitotoxic injections into the overlying cortex and were compared with nonlesion controls.

A glass pipette was used for all injections. Each pipette was pulled to a point, and the tip was broken $(\sim 50 \mu \mathrm{m})$. The pipette was then backfilled with 100 mm NMDA dissolved in $0.9 \%$ saline. The scalp was retracted, and holes were drilled above the PoS. Dura mater was removed, and the glass pipette was lowered into the PoS or the overlying cortex. Coordinates and volume for the PoS and cortex injections were based on a stereotaxic atlas (Paxinos and Watson, 1998) and are listed in Table 1.

Rats received an electrode implant immediately after NMDA injection during the same surgery. A hole was drilled through the skull over the
LMN, and the dura mater was removed. Six additional holes were drilled in the frontal, parietal, and occipital bones, and a small screw (Small Parts) was threaded into each hole to provide a secure anchor for the electrode. The electrode bundle was then lowered into the brain until the wires were dorsal to the LMN (bregma, $-4.55 \mathrm{~mm}$ anteroposterior, -1.0 $\mathrm{mm}$ mediolateral, $-8.5 \mathrm{~mm}$ dorsoventral). The plastic screw cuffs were then fastened to the skull with Grip Cement (DENTSPLY International). The scalp was sutured around the implant, and buprenorphine $(0.015 \mathrm{mg} /$ $\mathrm{kg}$ ) was administered as a postoperative analgesic. The animal was allowed to recover at least 1 week before commencing recording procedures.

\section{Apparatus}

Tracking and signal processing. All recording procedures were conducted in a dedicated recording room. This room included a black curtain that extended from the ceiling to the floor around the arena $(\sim 2.5 \mathrm{~m}$ diameter) to discourage the detection of visual cues outside of the arena. A white-noise generator produced white noise that was played through an overhead speaker to discourage the detection of random auditory cues.

A head stage containing a 10-channel unity gain operational amplifier and two light emitting diodes (LEDs; red for anterior and green for posterior) was connected to the electrode drive. The two LEDs were separated by $11 \mathrm{~cm}$ along the longitudinal axis of the rat with the red LED positioned above the rat's snout and the green LED positioned above the rat's back. The head stage was connected to a flexible 25-conductor cable, which transferred the electrode signals to an overhead commutator. After the commutator, electrical signals were amplified (P5 series; Grass Instruments) and bandpass filtered $(300-10,000 \mathrm{~Hz})$ before auditory and visual display on a loudspeaker and oscilloscope (model 2214; Tektronix), respectively. A dual time-amplitude window discriminator (model DDIS-1; BAK Electronics) was used to isolate single-unit spikes from background noise and produced an electrical square-wave pulse during spike detection. An overhead video camera (SONY XC-711) was used to monitor the positions of the red and green LEDs at 60 frames/s. Signals generated by the window discriminator at the occurrence of single-unit spikes and the concurrent LED positions were acquired by a computer (MacIntosh G4; Apple) running Labview software (National Instruments).

Arenas and screening/recording procedures. We used two recording arenas and procedures. The first arena consisted of a gray cylinder (diameter, $76 \mathrm{~cm}$; height, $51 \mathrm{~cm}$ ). A polarizing white cue card that subtended $\sim 100^{\circ}$ of arc along the wall surface was taped to the inside wall of the cylinder (Taube et al., 1990a). The cylinder was positioned on matted gray floor paper, which was replaced between recording sessions. Rats were screened daily for HD cells as reported previously (Taube, 1995a). Briefly, electrodes were connected to the head stage, and the rat was placed in the cylindrical recording arena. During screening and recording sessions, rats foraged for $20 \mathrm{mg}$ sugar pellets (Bio-Serve) dropped from an overhead food dispenser at pseudorandom time intervals around a $30 \mathrm{~s}$ average. Each of the 10 recording channels was evaluated for single-unit activity with $>2: 1$ signal-to-noise ratio (SNR). During detection of single-unit action potentials, the window discriminator was adjusted to isolate these waveforms from background noise. The occurrence of single-unit spikes was assessed visually for directional modulation, during which cell activity was recorded using a cue rotation procedure (Fig. 1A; Yoder and Taube, 2009). Briefly, this procedure included monitoring HD cell activity during five consecutive sessions: (1) standard ( $8 \mathrm{~min})$, in which the white cue card is positioned in the standard position; (2) rotation ( $8 \mathrm{~min}$ ), in which the white cue card is rotated $90^{\circ}$ clockwise (CW) or counterclockwise (CCW) from the standard location; (3) standard ( $8 \mathrm{~min})$, in which the white cue card is returned to the standard location; (4) darkness (16 min), in which the white cue card is removed from the cylinder and the overhead lights are extinguished; and (5) standard ( $8 \mathrm{~min}$ ), in which the white cue card is replaced at the standard location and the lights are turned on. Before the beginning of each session, the rat was placed in an opaque container, and the experimenter slowly carried the animal around the outside of the arena in both directions while rotating the container to disorient the animal.

The second arena was the dual-chamber apparatus, which consisted of a cylinder (diameter, $76 \mathrm{~cm}$; height, $43.5 \mathrm{~cm}$ ) connected to a rectangular 
A Rotation Procedure

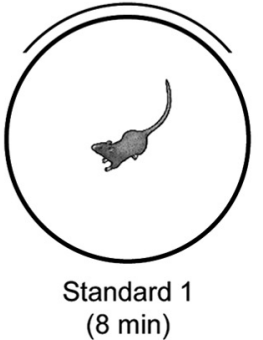

(8 $\mathrm{min})$

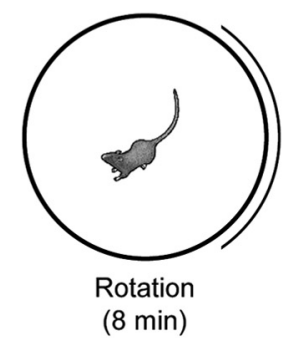

(8 $\mathrm{min})$

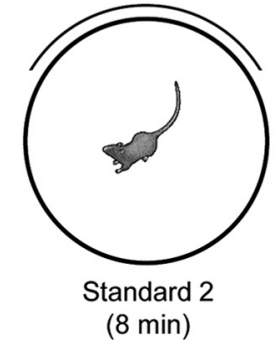

(8 min)

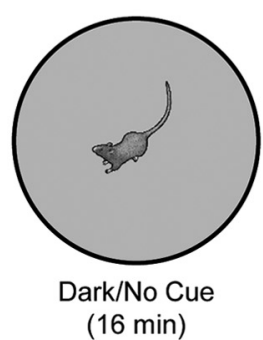

(16 $\mathrm{min})$

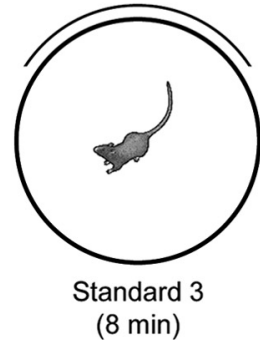

(8 $\mathrm{min})$

B Dual-Chamber Apparatus

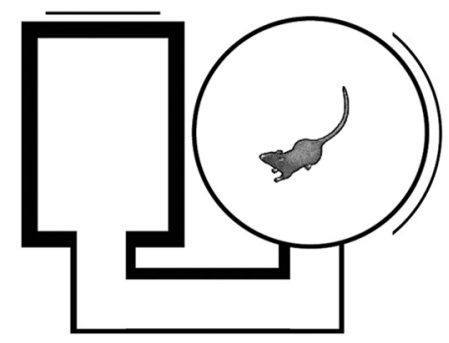

Standard Cylinder (4-8 min)

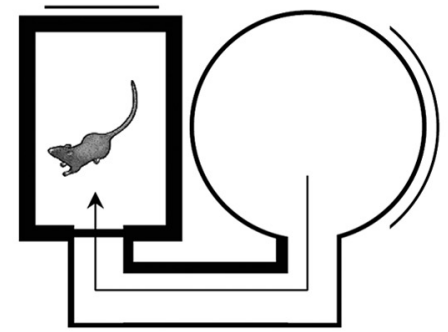

Novel Rectangle (8 min)

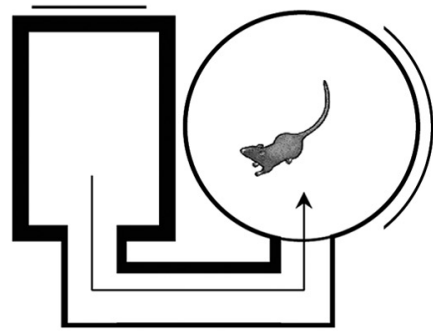

Return Cylinder (4-8 min)

Figure 1. HD cell recording procedure. $A$, The rotation procedure was conducted in a cylindrical arena containing a white polarizing cue card. HD cells were recorded across five consecutive sessions: (1) standard; (2) rotation; (3) standard; (4) darkness; and (5) standard. $\boldsymbol{B}$, The dual-chamber apparatus allowed assessment of HD cell activity as rats walked from a familiar arena (standard cylinder) to a novel rectangular arena, as well as during the rats' return to the familiar arena.

chamber $(51 \times 68.5 \mathrm{~cm})$ with slanted walls via a passageway (width: 15 $\mathrm{cm}$; center axis length of the long runway: $40.5 \mathrm{~cm}$ ). The cylinder contained a manually operated door that opened into the passageway. The rectangular chamber contained a white visual cue card that was shifted $90^{\circ} \mathrm{CCW}$ relative to that of the cylinder. The dual-chamber apparatus procedure was conducted as described previously (Taube and Burton, 1995). Briefly, after HD cell assessment in the five sessions described above, the rat was placed in the dual-chamber apparatus where three recording sessions were conducted: (1) standard cylinder ( $8 \mathrm{~min})$, in which the rat was placed in the cylindrical compartment with the cue card in the standard position; (2) novel rectangle $(8 \mathrm{~min})$, in which the door of the cylinder was opened to allow the rat to enter the passageway and rectangle, at which point the door of the cylinder was closed to prevent reentry to the cylinder; and (3) return cylinder (4 min), in which the door of the cylinder was opened and the rat was permitted to enter the cylindrical compartment, at which point the door was closed to confine the rat to this compartment.

\section{Data analysis}

HD tuning curves. The rat's HD was determined by calculating the angle between the positions of the anterior (red) and posterior (green) LEDs within a $256 \times 256$ pixel field at 60 frames/s. HD during each $16.667 \mathrm{~ms}$ epoch was then sorted into $606^{\circ}$ bins. The average firing rate as a function of $\mathrm{HD}$ within a session was calculated by dividing the total number of spikes by the amount of time the HD was within the angular limits of each bin. Data from cells that appeared to exhibit an increased firing rate as a function of HD were subjected to a Rayleigh test (Batschelet, 1981) to determine whether firing occurred randomly or clustered in a particular direction. Although a criterion of $r>0.20$ indicates significant directionality, these cells were not classified as HD cells because their tuning curves did not resemble those of "classic" HD cells, which have Rayleigh values $>0.40$.

Quantitative HD cell characteristics. Cell discharge characteristics were derived from the raw data using a triangular model (Taube et al., 1990a). For the triangular model, linear positive and negative slopes were manually fit to the raw data of the firing rate versus HD function to form a triangle with the $x$-axis as base. Using the triangular model, we calculated four characteristics of cell activity: (1) background firing rate (mean firing rate in all directions $18^{\circ}$ away from the $x$ intercept of each triangle leg); (2) peak triangular firing rate ( $y$ coordinate of the apex of the trian- gle); (3) triangular preferred firing direction ( $x$ coordinate of the apex of the triangle); and (4) directional firing range (the difference in degrees between the $x$ coordinates of the base of triangle legs). The signal-tonoise ratio was computed as the peak firing rate divided by the background firing rate. Cell discharge characteristics were derived from the raw data obtained during the first recording session (cylinder arena). Group comparisons for directional firing range and angular shift were based on individual cell values, except when multiple HD cells were recorded simultaneously. In this case, the mean value was calculated and reported as an individual cell value. For all other measures, each HD cell was computed as an individual case. For comparison with data from the triangular model, observed peak firing rate and preferred firing direction were also calculated. A Gaussian curve was fit to the raw data with the Gaussian mean corresponding to the preferred firing direction. A correlation coefficient was then calculated between a Gaussian curve and the raw data (Zhang, 1996).

Anticipatory time interval. The anticipatory time interval (ATI) was calculated for each HD cell using a time-shift analysis, as reported previously (Blair and Sharp, 1995). Cellular activity during angular head velocities $>60 \%$ s were used for ATI analyses. Cells that were recorded simultaneously with other cells on the same electrode were excluded from the ATI analysis.

Directional information content. Directional information content (IC) was calculated for each cell (Stackman and Taube, 1998): IC $=\sum p_{i}\left(\lambda_{i} / \lambda\right)$ $\log _{2}\left(\lambda_{i} / \lambda\right)$, where $p_{i}$ is the probability of the head pointing in the $i$ th bin, $\lambda_{i}$ is the firing rate when the head is pointed within the $i$ th bin, and $\lambda$ is the overall mean firing rate of the cell for all bins. An IC value of 0 indicates no relation between $\mathrm{HD}$ and firing rate, and a value $\geq 1$ indicates a strong relation between $\mathrm{HD}$ and firing rate. In cases in which multiple HD cells were recorded on the same electrode, directional IC scores were not calculated because $\lambda$ is potentially biased by the spikes of additional cell(s).

HD cell drift analysis. To determine the amount of drift exhibited by the preferred firing direction of an HD cell within a recording session, we plotted the directional heading that was associated with $>75 \%$ of the maximum within-session firing rate of the cell in $1 \mathrm{~s}$ time samples. A best-fit regression line was then applied to the $\mathrm{HD} \times$ time plot, and the absolute value of the slope was used as an index of stability in the pre- 


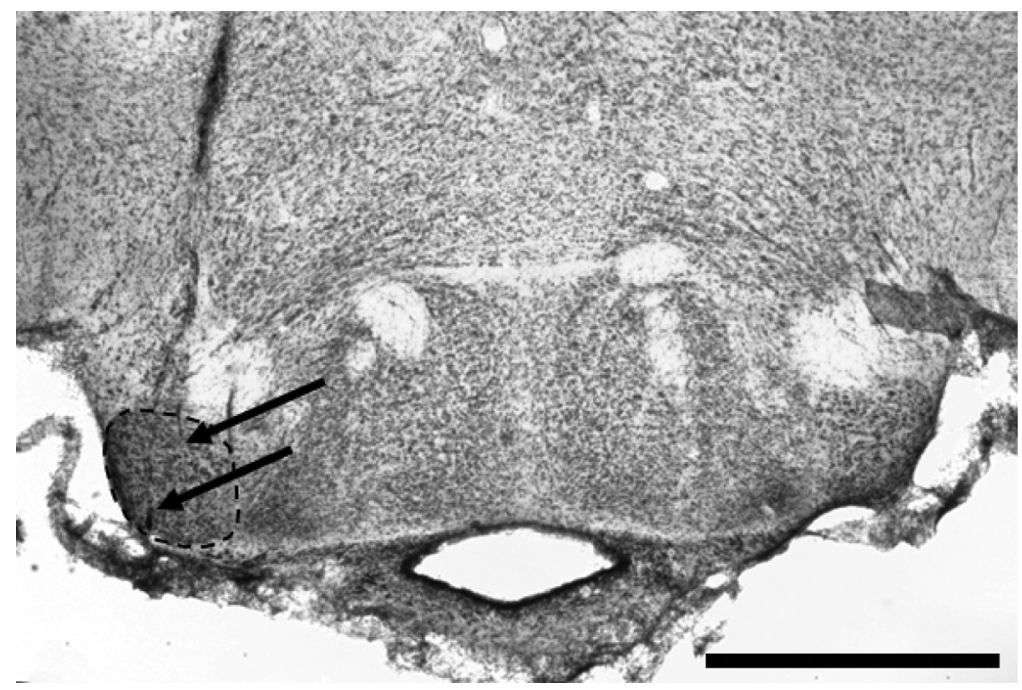

Figure 2. Histological verification of electrode position. Electrode tracks (arrows) were present in the LMN (dashed line). Scale bar, $1.0 \mathrm{~mm}$

ferred firing direction within the recording session. In the event of bidirectional drift, the session was separated into segments that corresponded to CW and CCW drifts. The distribution of absolute drift values from control and PoS lesion rats was compared with a hypothetical normal distribution with a Kolmogorov-Smirnov (K-S) one-sample test with Lilliefors correction (SPSS; IBM). Group drift values were then compared with a $t$ test or with a Mann-Whitney $U$ test if the distribution was not normal (SPSS).

HD cell shift analysis. To determine the amount of angular shift exhibited by an HD cell between sessions, we performed a correlation between the HD cell activity recorded in each session (Taube et al., 1990b). Briefly, the firing rate/HD functions for two recording sessions were shifted in $6^{\circ}$ steps, and the correlation between the curves was recalculated at each step. The angular shift of the cell was defined as the angle at which the correlation was maximal. For recording sessions during which multiple HD cells were recorded, the average shift of the preferred firing directions for simultaneously recorded cells was used for statistical calculations. This averaging method was used because previous studies indicate that, when multiple HD cells are recorded simultaneously, the preferred firing directions for all HD cells rotate in register (Taube et al., 1990b). Circular statistical evaluations of shifts in the preferred firing direction were performed on a personal computer with Oriana (Kovach Computing). A Watson-Williams $F$ test was used to compare distributions of shift values between groups. A $V$ test was used to determine whether a distribution of preferred firing direction shifts was uniform or was clustered around a predicted angle. The amount of dispersion in the circular data was quantified using the concentration parameter $\kappa$. The concentration parameter was then compared between groups (Batschelet, 1981); the modified analysis of Mardia (1972) was used when $0.40<r$-bar $<0.70$. Linear statistical comparisons were conducted on a personal computer with Statview (SAS Institute).

Dual-chamber apparatus. Two analyses were conducted to determine the HD cell response to self-movement between a familiar and a novel environment. The first analysis evaluated the response of the HD cell to an unfamiliar environment. The preferred firing direction of the HD cell in the first arena ("familiar cylinder") was compared with that of the novel environment ("novel rectangle"). A second analysis evaluated the reliability of the HD signal after the animal's return to the familiar arena. The preferred firing direction of the HD cell in the familiar cylinder was compared with that of the second episode in the cylinder (return cylinder).

\section{Histology}

After completion of electrophysiological recordings, rats received an overdose of sodium pentobarbital $(150 \mathrm{mg} / \mathrm{kg})$, and electrode tip locations were marked with constant anodal current (15 $\mu \mathrm{A}, 20 \mathrm{~s})$. Rats were killed by transcardial perfusion of normal saline, followed by $10 \%$ Formalin. Brains were then postfixed in $10 \%$ Formalin containing $2 \%$ potassium ferrocyanide for $24-48 \mathrm{~h}$ to produce a Prussian blue reaction at the electrode tip locations. Brains were removed from Formalin and placed in $20 \%$ sucrose for cryoprotection before being sectioned at $30 \mu \mathrm{m}$ on a cryostat. Brain sections containing the PoS and LMN were mounted on gelatin-coated microscope slides. Brain tissue was rehydrated before being stained with thionin and then dehydrated and covered with glass before examination under light microscopy. The recording electrode position in the LMN was verified by electrode tracks through the LMN and Prussian blue reaction at the ventral boundary of the LMN. PoS lesions were verified by visual examination of tissue damage. The extent of brain damage was reconstructed and manually drawn onto brain section diagrams recreated from Kjonigsen et al. (2011).

\section{Results \\ LMN HD cells}

Histological analysis revealed that recording electrodes penetrated the LMN of control ( $n=8$ including the two cortexlesioned animals) and PoS-lesioned $(n=11)$ rats (Fig. 2). In addition to HD cells, other cell types in LMN, including head pitch, linear velocity, and angular head velocity cells, were detected. These cells are not described here because they have been characterized previously (Stackman and Taube, 1998).

In the cortex-lesioned animals, neurotoxic damage was observed bilaterally in the retrosplenial and/or visual cortical areas overlying the PoS. In the PoS-lesioned animals, we observed some variability in the excitotoxic damage (Fig. 3). We intended to damage the PoS bilaterally in all rats but also included rats in our analyses that only had PoS damage ipsilateral to the recording site because the PoS $\rightarrow$ LMN projection is unilateral (van Groen and Wyss, 1990a). Additionally, because of the position of the dentate gyrus relative to the PoS, it is difficult to get a complete lesion of the PoS without damaging a small portion of the dentate. Eight of the PoS rats had minor damage to the dentate gyrus at the anteroposterior level of the PoS. We used NIH Image software to estimate the percentage of the dentate gyrus that was damaged in these animals. Across all PoS-lesioned rats, the damaged areas ranged from 0 to $8.5 \%$ of the entire dentate gyrus. This damage is unlikely to have contributed to the HD cell responses to landmark rotations, given that complete hippocampal lesions failed to disrupt landmark control of ADN HD cells (Golob and Taube, 1997, 1999).

Pairs of HD cells were simultaneously recorded on one occasion in a control rat, on one occasion in a cortex-lesioned rat, and on one occasion in a PoS-lesioned rat. The preferred firing directions of simultaneously recorded HD cells remained in register (were separated by an angular distance that remained relatively constant across sessions), and the average directional shift from both cells was used for all shift analyses.

We estimated the total number of cells recorded from LMN as the number of unique waveforms encountered on all electrodes, after the detection of an HD cell. We then used the total number of cells with directional tuning to estimate the percentage of cells in LMN that were categorized as HD cells. The estimated number of HD cells includes cells for which the waveform was lost after the first or second trial and therefore includes a greater number of 
cells than those used for the shift analyses. A total of $24 \mathrm{HD}$ cells (of 97 total cells; $24.7 \%$ ) were recorded from control rats, six HD cells (of 42 total cells; 14.3\%) were recorded from cortex-lesioned rats, and $35 \mathrm{HD}$ cells (of 130 total cells; 26.9\%) were recorded from PoS-lesion rats. Control and cortex-lesioned groups were then combined as a single control group for comparison with the PoSlesioned group. The percentage of HD cells in individual rats did not differ between the control and $\operatorname{PoS}$ groups $(Z$ test for proportions, $Z=-1.02, p=0.31)$. Additionally, the percentage of HD cells in control rats $(Z=0.25, p=0.9)$ and in PoS lesioned rats $(Z=0.65, p=.52)$ were similar to that reported by Stackman and Taube (1998), who found that 20 of 87 LMN cells (23\%) recorded were HD cells. However, Blair et al. (1998) reported that 23 of $41 \mathrm{LMN}$ cells (56\%) recorded were HD cells; the percentage of HD cells in the present control rats $(Z=4.32, p<0.01)$ and in PoS lesioned rats $(Z=3.4, p<$ $0.01)$ were significantly different from this value. These different percentages may reflect methodological differences in percentage estimation. For the total cell count, Blair et al. included only cells on electrodes that had at least one HD cell, whereas Stackman and Taube, along with the present study, included all cells isolated on all electrodes after the first HD cell was detected.

\section{HD cell firing characteristics}

Qualitatively, the tuning curves of HD cells from PoS-lesioned rats appeared to be similar to those from controls, although some tuning curves from lesioned rats were somewhat less smooth than those of control rats (see Fig. 5A). It is possible that this effect may have resulted from instability in the preferred firing direction of the cells (discussed further below). Nevertheless, most of the firing properties were similar for HD cells in control and PoS-lesioned rats (Table 2). The only measure that differed significantly between groups was the directional firing range, which was greater in PoSlesioned rats than in control rats $\left(t_{(40)}=\right.$ $3.93, p<0.01)$. It is possible that this increase resulted from PoS-lesioned rats' impaired use of visual cues (discussed below).

HD cells from control and cortex-lesioned rats were combined for comparison with LMN cells from previous studies. The firing characteristics of the present LMN HD cells differed somewhat from those reported previously for LMN HD cells (Blair et al., 1998; Stackman and Taube, 1998). The present ATI values (ATI $=72.5 \pm 13.01 \mathrm{~ms}$ ) were similar to those reported by Stackman and Taube (ATI $=95.8 \mathrm{~ms}$; one-sample $t_{(17)}=-1.79$,

\section{A Control}

\section{B PoS Lesion}

\section{Pos Lesions}
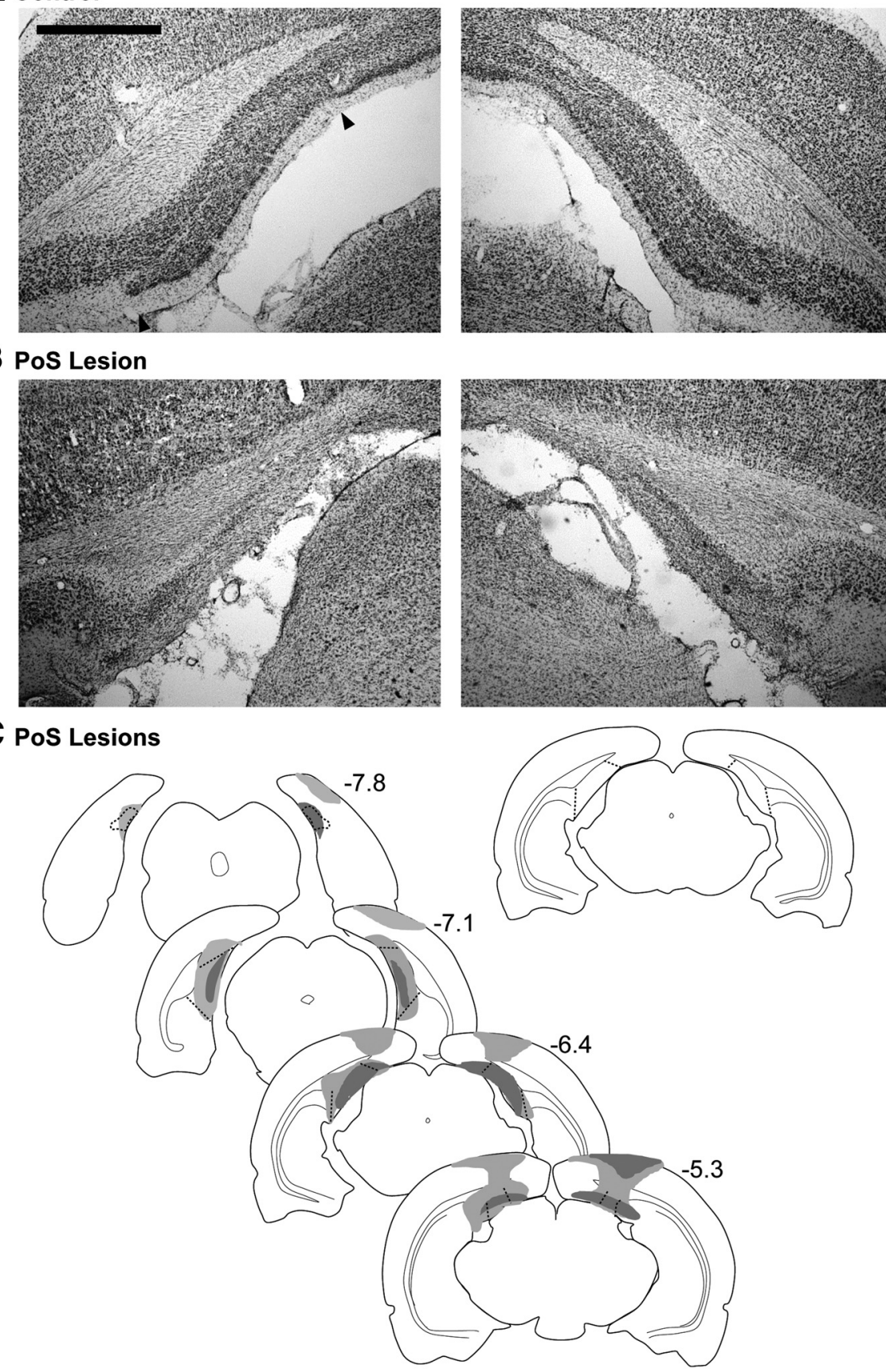

Figure 3. Histological reconstruction of PoS lesion. $A, B$, Coronal sections showing the PoS from a control rat $(A)$ and a PoSlesioned rat ( $\boldsymbol{B}$ ). NMDA injection into the PoS produced extensive damage to the PoS ipsilateral (left) and contralateral (right) to the recording site in the LMN. Arrowheads depict boundaries of the PoS. Scale bar, $1.0 \mathrm{~mm}$. Approximate location of images is depicted in the inset diagram, $6.4 \mathrm{~mm}$ caudal to bregma. C, Diagram of the lesion area after NMDA injection into the PoS. Light gray represents the most extensive damage, and dark gray represents the least extensive damage. Diagram sections are labeled with approximate rostrocaudal distance from bregma (recreated from Kjonigsen et al., 2011).

$p=0.09)$ but were greater than the ATI values reported by Blair et al. (ATI $=38.5$; one-sample $\left.t_{(17)}=2.61, p=0.02\right)$. Similarly, the present directional firing range $\left(156.8 \pm 7.9^{\circ}\right)$ was consistent with that of LMN cells in the study by Stackman and Taube $\left(168.2^{\circ}\right.$; one-sample $\left.t_{(18)}=-1.44, p=0.17\right)$ but differed significantly from the range reported by Blair et al. (79.9 ${ }^{\circ}$; one-sample $\left.t_{(18)}=9.75, p<0.01\right)$. The background firing rate of the present LMN cells ( $3.11 \pm 0.54$ spikes/s) also differed from both previous studies, with the present mean value falling between those of Blair 
Table 2. Firing characteristics of HD cells in the LMN

\begin{tabular}{lccc}
\hline Parameter & Control $(n=15)$ & Cortex $(n=4)$ & PoS lesion $(n=23)$ \\
\hline Background firing rate (spikes/s) & $3.3 \pm 0.68(0.21-9.8)$ & $2.1 \pm 0.16(1.8-2.5)$ & $3.50 \pm 1.05(0.06-22.0)$ \\
Signal-to-noise ratio & $34.5 \pm 21.4(4.0-332.0)$ & $40.9 \pm 15.4(13.3-68.9)$ & $59.8 \pm 24.6(3.8-488.3)$ \\
Peak firing rate (spikes/s) & $40.4 \pm 9.2(6.3-150.6)$ & $84.0 \pm 30.8(23.4-139.8)$ & $51.7 \pm 8.66(14.6-198.0)$ \\
Directional firing range $\left({ }^{\circ}\right)$ & $158.99 \pm 7.9(107.8-206.1)$ & $148.5 \pm 25.3(107.6-222.5)$ & $203.6 \pm 8.85(141.2-294.3)^{*}$ \\
Directional information content (bits) & $0.75 \pm 0.08(0.30-1.6)$ & $1.1 \pm 0.39(0.43-2.3)$ & $0.71 \pm 0.13(0.19-2.5)$ \\
Anticipatory time interval (ms) & $67.9 \pm 13.9(-23.8-161.8)$ & $88.7 \pm 36.0(-3.2-148.7)$ & $121.5 \pm 25.4(-161.8-440.9)$ \\
Rayleigh's $r$ value & $0.60 \pm 0.03(0.39-0.90)$ & $0.74 \pm 0.07(0.58-0.86)$ & $0.57 \pm 0.03(0.30-0.81)$ \\
\hline
\end{tabular}

Data are shown as mean \pm SEM (range). Note that HD cells from control and cortex-lesioned animals were combined into a single control group for statistical comparison with PoS-lesioned cells. ${ }^{*} p<0.01$.

et al. ( 1.5 spikes/s; one-sample $\left.t_{(18)}=2.78, p=0.013\right)$ and Stackman and Taube $\left(5.11\right.$ spikes/s; one-sample $t_{(18)}=-3.86, p<$ $0.01)$.

\section{HD cell stability within sessions}

The preferred firing direction of an HD cell typically remains stable and represents a single direction within a recording session when visual cues are available. Therefore, if the PoS is necessary to convey visual information to LMN HD cells, then PoS lesions may cause HD cells to become unstable within a recording session. To test whether an intact PoS is necessary for HD cell stability within a session, we compared the preferred firing direction of each HD cell during the first 2 min of a recording session with that of the last $2 \mathrm{~min}$. In control rats, HD cells $(n=16)$ had a mean vector of $r_{(16)}=0.99\left(2.61^{\circ} \pm 9.48^{\circ}\right.$, mean \pm SD; Fig. 4 , example in $A$, group data are shown in $C$, left). A $V$ test indicates that these shifts were significantly clustered around $0^{\circ}\left(V_{(16)}=\right.$ $0.99, u=5.6, p<0.01)$. In PoS-lesioned rats, HD cells $(n=22)$ had a mean vector of $r_{(22)}=0.82\left(11.0^{\circ} \pm 36.4^{\circ}\right.$, mean $\pm \mathrm{SD}$; Fig. 4 , example in $B$, group data are shown in $C$, right). A $V$ test indicates that these shifts were also significantly clustered around $0^{\circ}\left(V_{(16)}=0.99, u=5.6, p<0.01\right)$. However, the circular histograms appear to show that the PoS-lesioned group displayed more variability than controls. Therefore, we compared the concentration parameter between the control $(\kappa=37.0)$ and PoS-lesioned $(\kappa=3.09)$ groups as a measure of variability. The PoS-lesioned group had a significantly lower concentration than the control group $\left(F_{(15,21)}=29.2, p<0.01\right)$. Given this greater variability of shifts, we tested whether the shift was arbitrary or was instead because of a gradual but steady drift in the preferred firing direction across the session. Therefore, we quantified the absolute preferred firing direction drift of each HD cell during the first standard recording session, as reported previously (Yoder and Taube, 2009). The drift was always unidirectional, and a regression line was fit to the data. The absolute value of the slope served as an index of preferred firing direction drift within the recording session. HD cells in control rats had a mean absolute drift of $0.032 \pm .006^{\circ} / \mathrm{s}$ (range, $0.0-0.093^{\circ} / \mathrm{s}$ ), and HD cells in PoS-lesioned rats had a mean absolute drift of $0.067 \pm .014^{\circ} \%$ (range, $0.002-0.249^{\circ}$ s; Fig. 4D). These drift values were not significantly different between groups, although the comparison approached significance (Mann-Whitney $\mathrm{U}=127.5, p=0.06$; $\mathrm{K}-\mathrm{S}$ test for normality, $D=0.259, p<0.01)$. Thus, PoS lesions did not markedly disrupt the ability of HD cells to represent a single direction within a recording session.

As an additional measure of within-session stability, we evaluated the directional firing range of HD cells across the three standard recording sessions (sessions 1, 3, and 5) with a mixed group $\times$ session ANOVA. We note that this measure (as well as other between-session measures) included only those HD cells for which single-unit activity was isolated across all five recording sessions. Across sessions, the control and PoS-lesioned groups had significantly different directional firing ranges (group, $F_{(1,37)}=$ $15.7, p<0.01)$, which is consistent with the $t$ test reported above). The directional firing range also increased slightly across recording sessions for both groups (session, $F_{(2,74)}=4.04, p=0.02$ ), and this increase occurred between sessions 1 and 3 (StudentNewman-Keuls test, $p<0.05)$. However, the rate of increase did not differ between groups (group $\times$ session, $F_{(2,74)}=0.56, p=$ 0.58 ). Thus, the directional firing range was greater for the PoSlesioned group than the control group, and both groups showed significant variability across trials, although this variability did not differ between groups.

\section{HD cell stability across sessions}

Three comparisons were used to quantify HD cell stability across sessions (the ability of an HD cell to reliably represent a single direction over time within a given environment). The first comparison determined the amount of shift in the cell's preferred firing direction between the first and second standard sessions (session 1 vs session 3). A second comparison determined the amount of shift in the cell's preferred firing direction between the second and third standard sessions (session 3 vs session 5), and a third comparison determined the amount of shift between the first and last standard sessions (session 1 vs session 5 ).

Control HD cells remained quite stable across the three standard sessions. Figure $5 B$ (left) shows that the distribution of angular shifts between sessions 1 and 3 had a mean vector of $r_{(16)}=$ 0.95 (mean $\left.\pm \mathrm{SD}, 0.07^{\circ} \pm 19.0^{\circ}\right)$. A $V$ test indicates that this distribution was significantly clustered around $0^{\circ}\left(V_{(16)}=0.95\right.$, $u=5.4, p<0.01)$. The preferred directions of cells in the PoSlesioned group were also stable between sessions 1 and $3\left(V_{(20)}=\right.$ $0.33, u=2.1^{\circ}, p=0.02$; Fig. $5 B$, right). However, despite the significant clustering around $0^{\circ}$, the distribution of preferred firing direction shifts appeared to be more variable for the PoSlesioned group, as indicated by a smaller mean vector $\left(r_{(20)}=\right.$ 0.36 , mean $\left.\pm \mathrm{SD}, 21.4^{\circ} \pm 81.7^{\circ}\right)$. Therefore, we compared the concentration parameter of the control group $(\kappa=9.57)$ with that of the PoS-lesioned group $(\kappa=0.78)$. The concentration parameter was significantly different between groups $(Z=3.74$, $p<0.01$ ), indicating that these distributions had different angular variances.

We then compared the preferred firing direction shift between sessions 3 and 5 (Fig. 5C). The shifts of HD cells in control rats had a mean vector of $r_{(16)}=0.95\left(\right.$ mean $\left.\pm \mathrm{SD}, 0.39^{\circ} \pm 18.7^{\circ}\right)$. A $V$ test indicates that these shifts were significantly clustered around $0^{\circ}\left(V_{(16)}=0.95, u=5.4, p<0.01\right)$. The shifts of HD cells in PoS-lesioned rats had a mean vector of $r_{(20)}=0.33$ (mean \pm $\left.\mathrm{SD}, 0.10 .8^{\circ} \pm 85.6^{\circ}\right)$. A $V$ test indicates that these shifts were significantly clustered around $0^{\circ}\left(V_{(20)}=0.32, u=2.0, p=0.02\right)$. However, as with the comparison between sessions 1 and 3 , the concentration parameter was significantly different between 
A Control - Preferred Firing Direction Drift: $\mathbf{- 0 . 0 3 1 \%} / \mathrm{sec}$
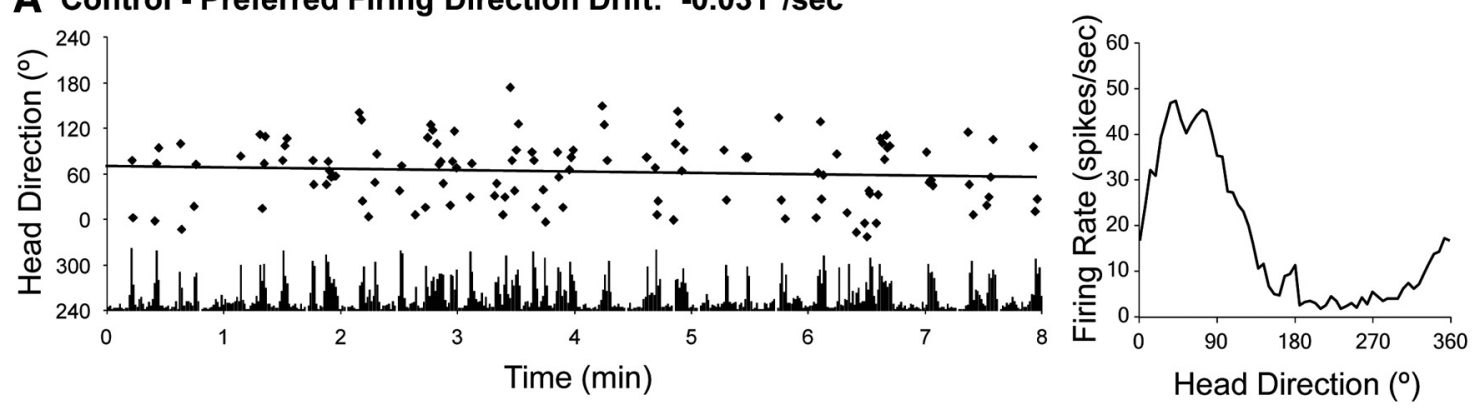

B PoS Lesion - Preferred Firing Direction Drift: $0.067^{\circ} / \mathrm{sec}$
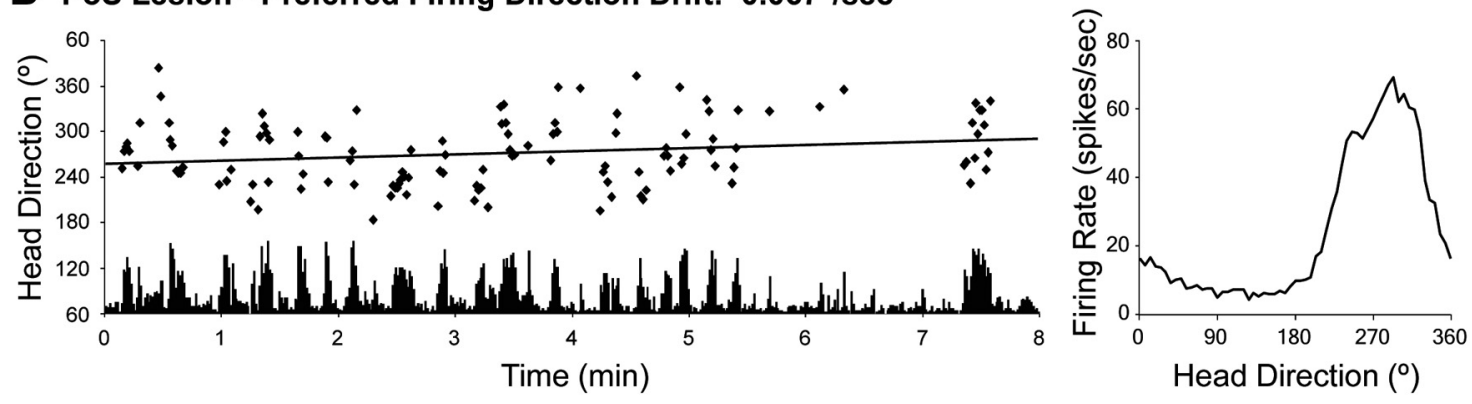

\section{Preferred Firing Direction Shift}

D Preferred Firing Direction Drift
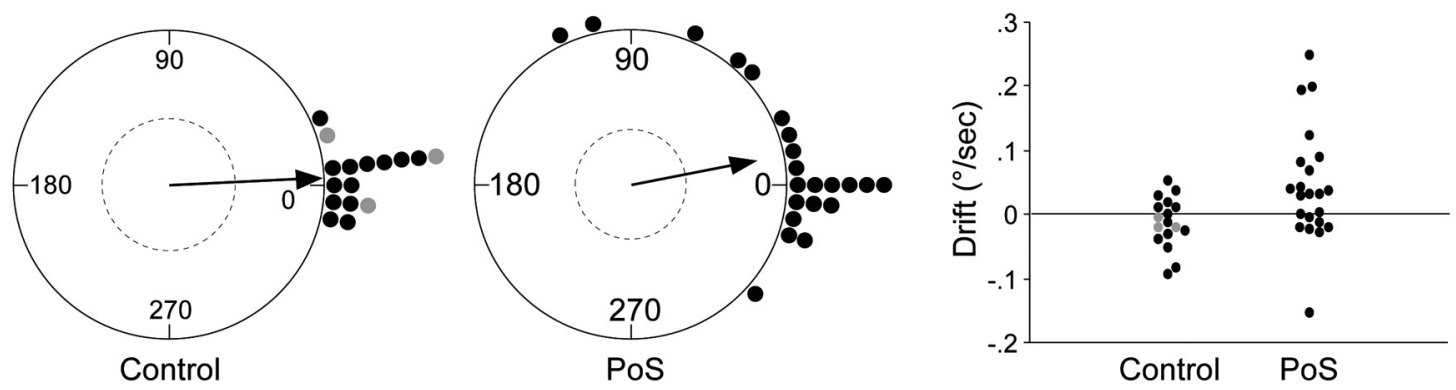

Figure 4. HD cell stability during the first standard recording sessions. $A$, Left, HD cells in control rats remained relatively stable, although the preferred firing direction drifted slightly for most cells. Right, HD versus firing rate tuning curve for the depicted cell. $\boldsymbol{B}$, Left, HD cells in PoS-lesioned rats showed greater drift in their preferred firing directions than those in control rats. Right, Tuning curve for the depicted cell. C, Preferred firing direction shift between the first $2 \mathrm{~min}$ and last $2 \mathrm{~min}$ of the recording session. $\boldsymbol{D}$, Preferred firing direction drift values for all cells in control and PoS-lesioned animals. For $\boldsymbol{C}$ and $\boldsymbol{D}$, there were no significant differences in the mean values between control and PoS-lesioned animals. Although the PoS-lesioned animals appeared to display more variability on both measures compared with controls, the differences were not significant. Note that absolute drift values were used for statistical analyses.

groups, with the lesion group displaying more variability than controls (control, $\kappa=9.95 ;$ PoS lesion, $\kappa=0.70 ; Z=3.89, p<$ $0.01)$.

A third comparison evaluated the preferred firing direction shift between sessions 1 and 5 (Fig. 5D). HD cells from control rats showed little shift in their preferred directions, with the distribution mean vector of $r_{(16)}=0.98\left(\right.$ mean $\left.\pm \mathrm{SD}, 4.3^{\circ} \pm 11.3^{\circ}\right)$. A $V$ test indicates that these shifts were significantly clustered around $0^{\circ}\left(V_{(16)}=0.98, u=5.5, p<0.01\right)$. In contrast, for PoS-lesioned rats, the shifts between sessions 1 and 5 had a mean vector of $r_{(20)}=0.19\left(\right.$ mean $\left.\pm \mathrm{SD}, 57.0^{\circ} \pm 104.3^{\circ}\right)$, and a $V$ test indicates that these shifts were not significantly clustered around $0^{\circ}\left(V_{(20)}=0.10, u=0.66, p=0.26\right)$. Furthermore, the concentration parameter was significantly different between groups (control, $\kappa=26.08$; PoS lesion, $\kappa=0.39 ; Z=4.71, p<0.01$ ). Thus, HD cells in control rats remained quite stable across all three standard recording sessions, whereas those of PoS-lesioned rats became less stable across standard recording sessions.

In summary, comparison of stability within and across standard sessions shows that there tended to be more drift of the preferred firing direction within a session in the lesioned rats but that the drift amount over $8 \mathrm{~min}$ was not sufficient to reach statistical significance. Furthermore, the instability of the preferred firing direction was not apparent when adjacent control sessions were compared (session 1 vs 3 and session 3 vs 5), although, again, there tended to be more variance in the lesion group. The instability of the preferred firing direction only became significant when comparing across longer temporal intervals (i.e., session 1 vs 5 ).

\section{Cue control of preferred firing direction}

With the visual cue rotated $90^{\circ}$ from the standard position, a $90^{\circ}$ shift in the cell's preferred firing direction indicates strong landmark control of the HD signal. In control rats, the distribution of preferred firing direction shifts indicates that the visual cue strongly influenced HD cell activity (mean vector of $r_{(16)}=0.96$, mean $\pm \mathrm{SD}, 73.3^{\circ} \pm 15.6^{\circ}$; Fig. 5 , example in $A$, left; group data are shown in $E$, left). These shifts were significantly clustered around the predicted value of $90^{\circ}, V_{(16)}=0.92, \mathrm{u}=5.2, p<0.01$. Nevertheless, the cells showed a slight under-rotation relative to 


\section{Control}

\section{A Representative Tuning Curves}

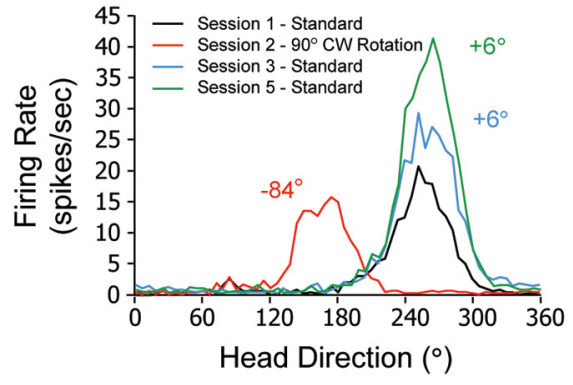

\section{B Session 1 vs. Session 3}

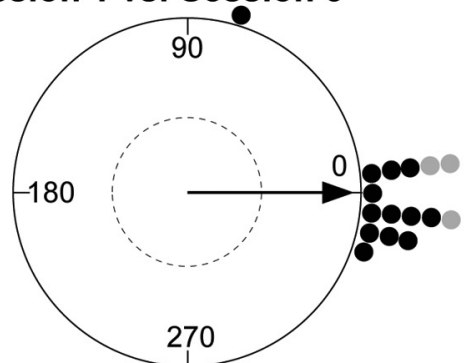

\section{Session 3 vs. Session 5}

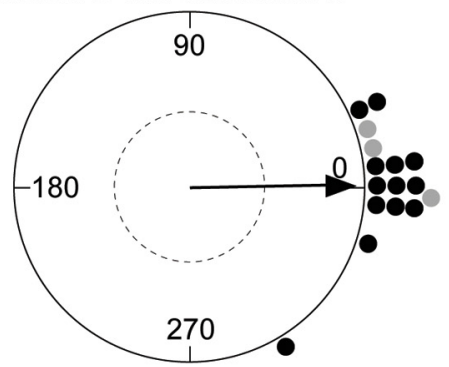

D Session 1 vs. Session 5
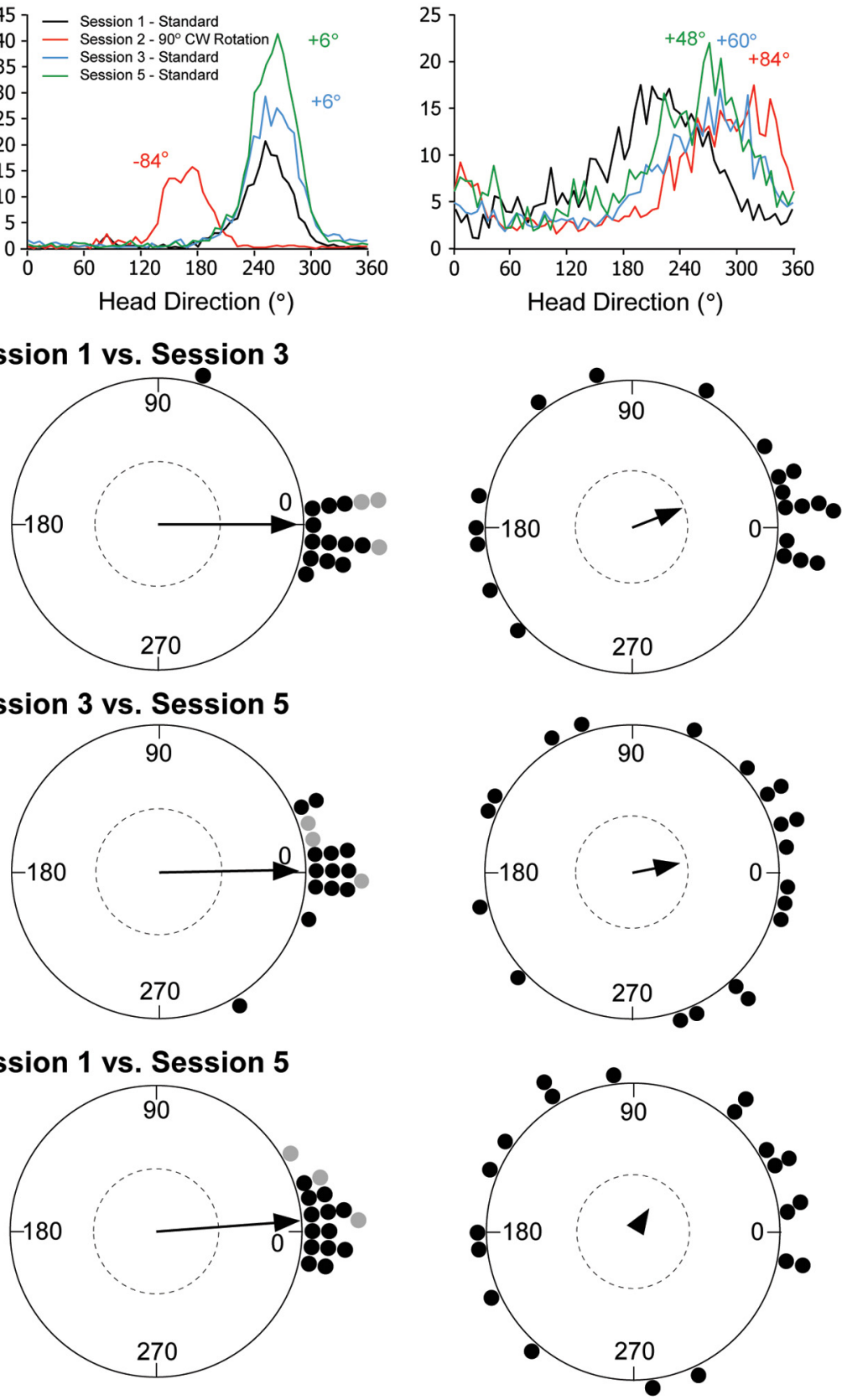

\section{E Session 1 vs. Session 2 (90 Rotation)}
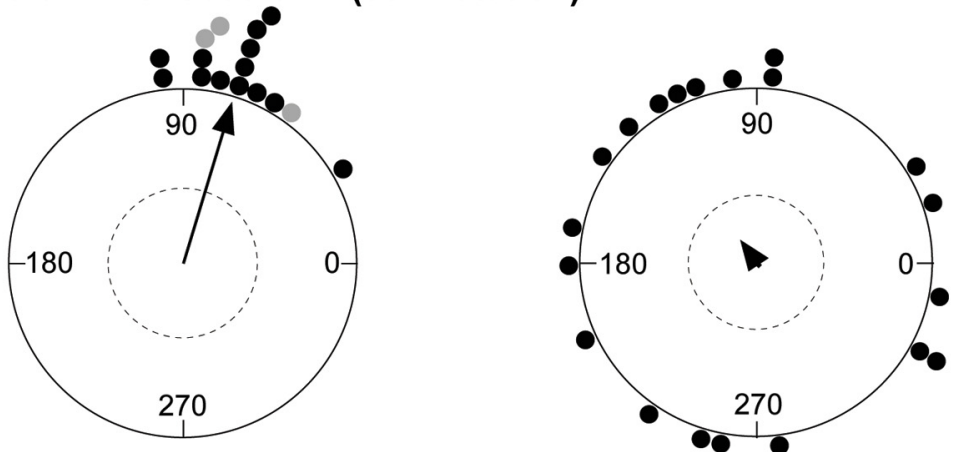

Figure 5. Stability and visual cue control of the preferred firing direction. $\boldsymbol{A}$, Representative tuning curves from $\mathrm{HD}$ cells recorded from control and PoS-lesioned rats during sessions $1-3$ and 5 . The cue card was in the same position for sessions 1,3 , and 5; for the cue; under-rotations in control animals are common and have been reported previously (Taube et al., 1990b). In PoS lesioned rats, HD cells showed considerable variability in the shift of the preferred firing direction in response to visual cue rotation; mean vector $r_{(20)}=0.17, \mu=$ 125.7, $\mathrm{SD}=108.4^{\circ}$ (Fig. 5, example in $A$, right; group data are shown in $E$, right). A $V$ test indicates that these shifts were not significantly clustered around $90^{\circ}\left(V_{(20)}=\right.$ $0.14, u=0.86, p=0.20$ ). Thus, HD cells of control rats showed preferred firing direction shifts that approximately corresponded to the rotated cue card, whereas the preferred firing directions of HD cells from PoS-lesioned rats shifted randomly after the card was rotated.

Path integration maintenance of HD signal

Dark/no cue sessions

A path integration mechanism is thought to maintain HD signal stability during darkness or when familiar visual landmarks are not available (Taube and Burton, 1995; Taube, 1995a; Goodridge et al., 1998; Yoder et al., 2011a). However, this path integration mechanism accumulates errors over time, resulting in a drift of the cell's preferred firing direction throughout a dark recording session. Figure 6, A and $B$, depicts examples of preferred firing direction drift of HD cells over time in control and PoS-lesioned animals, respectively. We quantified this spatial updating ability by comparing the preferred firing direction of each HD cell during the first 2 min with that of the last $2 \mathrm{~min}$ in a dark recording session without the presence of

session 2, the cue card was rotated $90^{\circ} \mathrm{CW}$. The HD cell recorded from a control animal (left) shifted in the same direction as the cue card but showed a slight under-rotation. In contrast, the cell recorded from a PoS-lesioned animal (right) shifted $84^{\circ}$ in the opposite direction of the rotated cue card. Numbers indicate the angular shift of the preferred firing direction relative to session 1. $\boldsymbol{B}-\boldsymbol{D}$, Angular preferred firing direction shifts, in polar coordinates, between standard recording sessions (sessions 1,3, and 5) with the lights on and cue card in the 3:00 position. HD cells in control rats showed little preferred firing direction shift across standard recording sessions, whereas the shifts of HD cells in PoS-lesioned rats were uniformly distributed for session 1 versus session 3 , session 1 versus session 5 , and session 3 versus session 5. Gray data points represent cells recorded from animals with cortex lesions. $\boldsymbol{E}$, $\mathrm{HD}$ cell responses to a $90^{\circ}$ cue rotation, with values adjusted to depict preferred firing direction shifts on the same scale, whether the cue card was rotated CW or CCW. Most HD cells in control rats showed a slight under-rotation of preferred firing direction. In contrast, cells from PoS-lesioned rats showed a uniform distribution of preferred firing direction shifts. 


\section{A Control - Preferred Firing Direction Drift: $-0.072 \%$ sec}
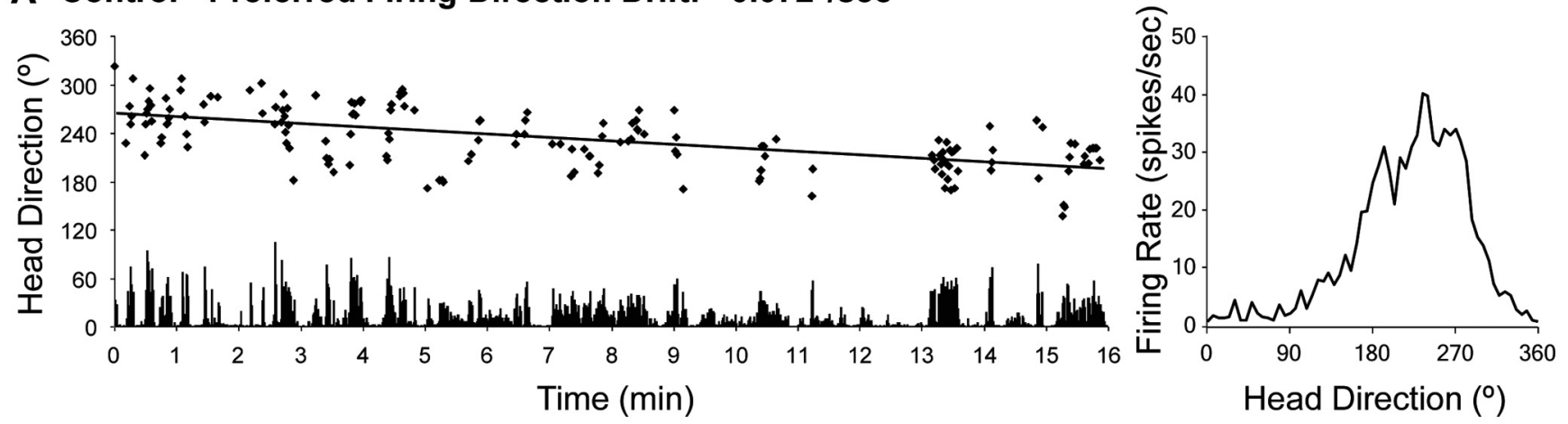

B PoS Lesion - Preferred Firing Direction Drift: $-0.219 \%$ sec

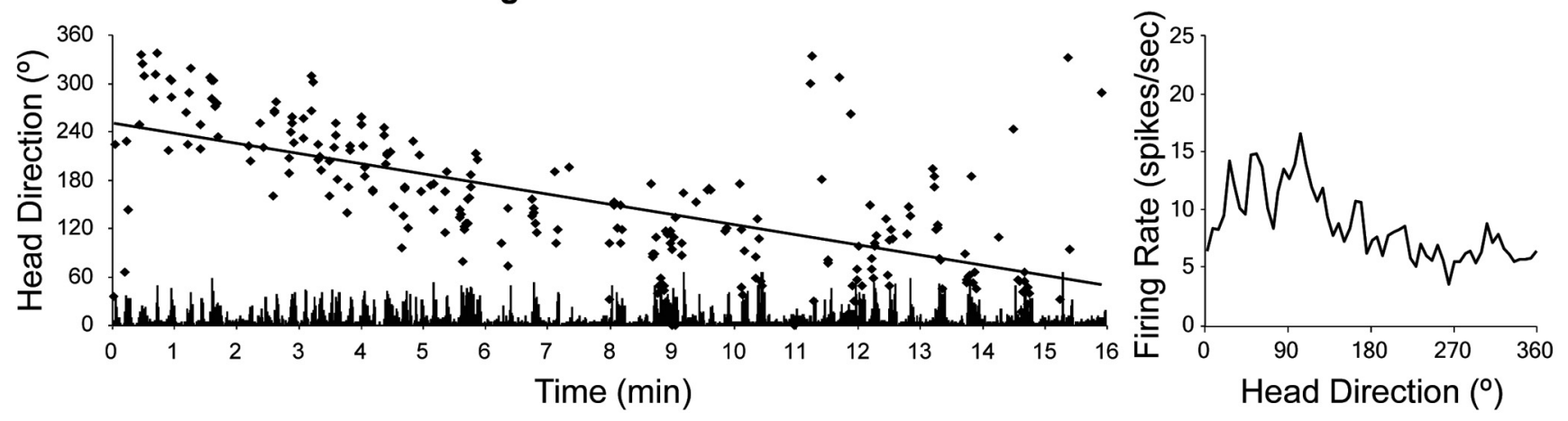

\section{Preferred Firing Direction Shift}
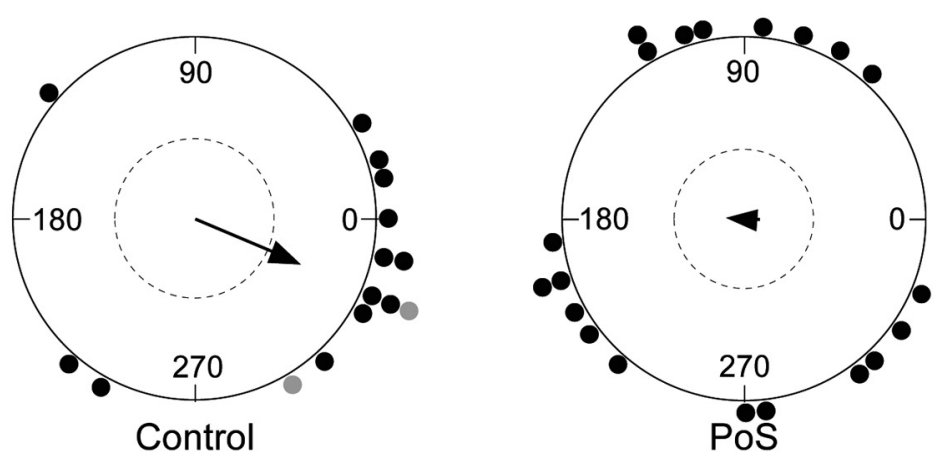

D Preferred Firing Direction Drift

Figure 6. HD cell stability during dark recording sessions. $A$, Left, HD cells in control rats remained relatively stable in darkness, although the preferred firing direction drifted slightly for most cells. Right, Tuning curve for the cell depicted. $\boldsymbol{B}$, Left, Some HD cells in PoS-lesioned rats became unstable and showed considerable preferred firing direction drift during the dark recording session. Right, Tuning curve for the cell depicted, indicating drift of preferred firing direction. C, Preferred firing direction shift between the first 2 min and last 2 min of the recording session. $\boldsymbol{D}$, Preferred firing direction drift values for all cells in control and PoS-lesion animals. Note that absolute drift values were used for statistical analyses. Gray data points represent cells recorded from animals with cortex lesions.

the white cue card. Most cells were recorded for $16 \mathrm{~min}$ in the dark session. However, three cells from the control group and two cells from the PoS-lesioned group were only recorded for 8 min. To compare the shift values across all cells as a measure of stability across $16 \mathrm{~min}$, we doubled the preferred firing direction shift for cells that were recorded for $8 \mathrm{~min}$. In control rats, HD cells $(n=15)$ had a mean vector of $r_{(15)}=0.62$ (mean $\pm \mathrm{SD}$, $336.9^{\circ} \pm 55.6^{\circ}$; Fig. $6 C$, left $)$. A $V$ test indicates that these shifts were significantly clustered around $0^{\circ}\left(V_{(15)}=0.57, u=3.14, p<\right.$ $0.01)$. In PoS-lesioned rats, HD cells $(n=20)$ had a mean vector of $r_{(20)}=0.10$ (mean $\pm \mathrm{SD}, 175.9^{\circ} \pm 121.5^{\circ}$; Fig. $6 C$, right), and a $V$ test indicates that these shifts were not significantly clustered around $0^{\circ}\left(V_{(20)}=-0.10, u=0.67, p=0.75\right)$. Therefore, we compared the concentration parameter between control $(\kappa=$ $1.53)$ and PoS-lesioned $(\kappa=0.21)$ groups as a measure of variability. The PoS-lesioned group had a significantly lower concentration than the control group $(Z=2.14, p<0.05)$. Given the greater variability of shifts for the PoS-lesioned group, we then calculated the absolute value of the preferred firing direction drift over time within dark recording sessions. HD cells in control rats showed a mean absolute preferred firing direction drift of $0.057^{\circ} \%$ s (range, $0.002-0.198^{\circ} / \mathrm{s}$ ). In contrast, the preferred firing directions from HD cells in PoS-lesioned rats had a mean absolute drift of $0.211^{\circ} \mathrm{s}$ (range, $0.003-0.874^{\circ} \mathrm{s}$ ). Group drift values are depicted in Figure $6 \mathrm{D}$. Overall, cells from PoS-lesioned rats drifted a greater amount than cells from control/cortex-lesioned 


\section{Control}

\section{A Familiar Cylinder $\rightarrow$ Novel Rectangle}
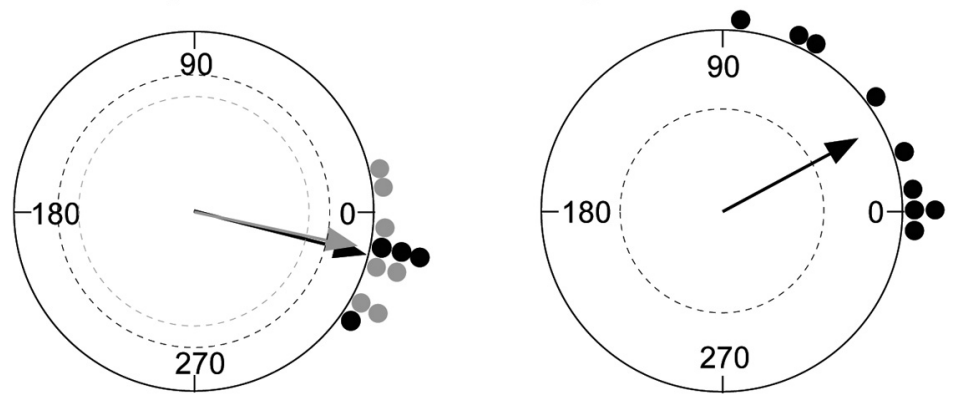

\section{B Familiar Cylinder $\rightarrow$ Return Cylinder}
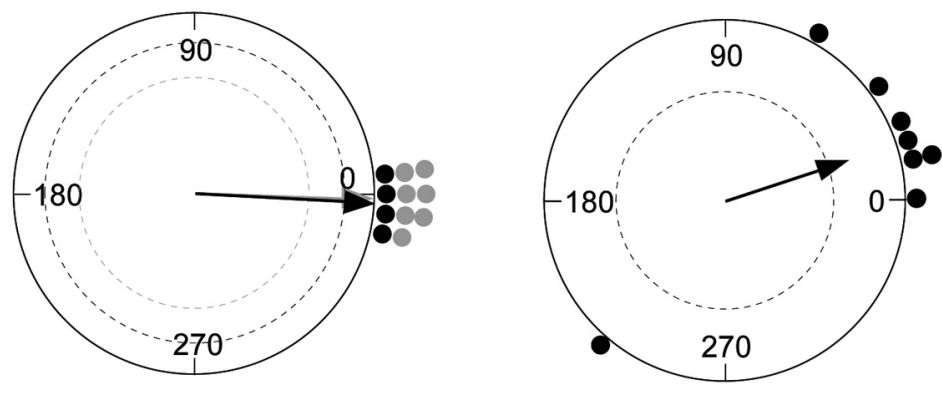

Figure 7. Preferred firing direction shift in the dual-chamber apparatus. $A, H D$ cells in control rats showed a slight $C W$ shift when the animal walked from the standard cylinder to the novel rectangle, in which the cue card was rotated $90^{\circ} \mathrm{CCW}$ relative to the cylinder. In contrast, HD cells in PoS-lesioned rats shifted slightly CCW. B, HD cells in both control and PoS-lesioned rats realigned when the animal returned to the cylinder, although the PoS-lesioned group showed slightly (nonsignificant) greater variability. Gray points represent ADN cells described previously (Taube and Burton, 1995).

ferred firing direction shifts for the control group had a mean vector of $r_{(11)}=$ $0.97\left(\right.$ mean $\left.\pm \mathrm{SD}, 345.78^{\circ} \pm 14.1^{\circ}\right)$. A $V$ test indicates that the preferred firing direction shifts for the control group were significantly clustered around $0^{\circ}\left(V_{(11)}=\right.$ $0.94, u=4.41, p<0.01$; Fig. $7 A$, left). For cells from PoS-lesioned rats, the distribution of preferred firing direction shifts between the standard cylinder and novel rectangle was more variable and had a mean vector of $r_{(9)}=0.86$ (mean $\pm \mathrm{SD}$, $\left.28.5^{\circ} \pm 32.1^{\circ}\right)$. A $V$ test showed that the preferred firing direction shifts for HD cells from PoS-lesioned rats were also significantly clustered around $0^{\circ}\left(V_{(9)}=\right.$ 0.75, $u=3.19, p<0.01$; Fig. 7A, right). However, the concentration parameter for the PoS-lesioned group was significantly different from the control group (control, $\kappa=12.68$; PoS lesion, $\kappa=2.61$; $\left.F_{(10,8)}=4.98, p<0.05\right)$. Thus, damage to the PoS moderately disrupted the ability of HD cells to maintain a stable preferred firing direction during navigation into a novel environment.

We then asked whether the HD cell signal would regain its orientation after return to the familiar cylinder, after the animal had walked to the novel rectangle. Previous studies showed that control HD cells reliably reorient to the familiar landmarks when the animal returns from the novel environment to the familiar one, re-

rats (Mann-Whitney $U=79.0, p=0.018$; K-S test for normality, $D=0.27, p<0.01)$. Therefore, the PoS appears to contribute to HD cell stability in darkness.

\section{Dual-chamber apparatus}

The dual-chamber apparatus procedure has been shown previously to cause the preferred firing direction of ADN HD cells to shift slightly between the standard cylinder and novel rectangle sessions, only to return to its original orientation when the rat returns to the return cylinder session (Taube and Burton, 1995). Therefore, we calculated the preferred firing direction shift of each cell between the standard cylinder session and the novel rectangle session and between the standard cylinder session and the return cylinder session.

For HD cells in control rats, the distribution of preferred firing direction shifts between the standard cylinder and novel rectangle had a mean vector of $r_{(4)}=0.98$ (mean $\pm \mathrm{SD}, 342.1^{\circ} \pm 10.4^{\circ}$; Fig. $7 A$, left). A $V$ test indicates that these shifts were significantly clustered around $0^{\circ}\left(V_{(4)}=0.94, u=2.6, p<0.01\right)$. This distribution of preferred firing direction shifts was similar to that of a previous study of ADN HD cells, in which the distribution of shifts had a mean vector of $r_{(7)}=0.96$ (mean $\pm \mathrm{SD}, 347.9^{\circ} \pm$ $15.4^{\circ}$; Taube and Burton, 1995). Previous studies have indicated that HD cells throughout the HD circuit are linked, with all HD cells responding similarly to a particular cue manipulation (Yoganarasimha et al., 2006; Taube, 2007). Because the preferred firing direction shifts of LMN and ADN HD cells were similar (Watson-Williams test, $F_{(1,9)}=0.38, p=0.55$ ), these cells were combined into a single control group for comparison with LMN HD cells from PoS-lesioned rats. Overall, the distribution of pre- gardless of whether the animal is picked up and carried between environments or whether the animal walks between environments (Taube and Burton, 1995; Yoder et al., 2011a). Similar results were found in the present study, with the preferred firing directions of control LMN HD cells remaining consistent between the two cylinder sessions (mean vector of $r_{(4)}=0.99$; mean $\pm \mathrm{SD},-3.0^{\circ} \pm 6.7^{\circ}$; Fig. $7 B$, left). A $V$ test indicates that these shifts were significantly clustered around $0^{\circ}\left(V_{(4)}=0.99\right.$, $u=2.8, p<0.01)$. ADN HD cells in a previous study showed a similar distribution of preferred firing direction shifts between the standard and return cylinder sessions (mean vector of $r_{(7)}=$ 0.99 ; mean $\left.\pm \mathrm{SD}, 358.3^{\circ} \pm 6.2^{\circ}\right)$ and were significantly clustered around $0^{\circ}\left(V_{(7)}=0.99, u=3.7, p<0.01\right)$. The preferred firing direction shifts of LMN cells in the present study did not differ significantly from those of ADN cells in the previous study (Watson-Williams test, $\left.F_{(1,10)}=3.15, p=0.11\right)$. Therefore, we combined LMN and ADN cells for comparison with cells from the PoS-lesioned group. The distribution of preferred firing direction shifts for the combined control group had a mean vector of $r_{(11)}=0.99\left(\right.$ mean $\left.\pm \mathrm{SD}, 357.8^{\circ} \pm 6.4^{\circ}\right)$. A $V$ test indicates that the preferred firing direction shifts for the control group were significantly clustered around $0^{\circ}\left(V_{(11)}=0.99, u=4.66, p<0.01\right.$; Fig. $7 B$, left). For PoS-lesioned rats, the preferred firing directions of HD cells also remained relatively stable across the standard and return cylinder sessions $\left(V_{(8)}=0.68, u=2.73, p<0.01\right.$; Fig. $7 B$, right). Nevertheless, the distribution of preferred firing direction shifts appeared to be somewhat more variable than that of control cells (mean vector of $r_{(8)}=0.72$; mean \pm SD, $18.6^{\circ} \pm 46.4^{\circ}$; Fig. $7 B$, right). Indeed, comparison of the concentration parameter 
for the control group $(\kappa=59.9)$ and the PoS-lesioned group $(\kappa=1.41)$ revealed that these distributions had different angular variances $\left(F_{(7,10)}=46.5, p<0.01\right)$. We note that the low concentration for the PoS-lesioned group may have been influenced heavily by the one outlier. Overall, HD cells of both control and PoSlesioned rats showed a relatively stable preferred firing direction between the standard cylinder and return cylinder sessions, but the PoS-lesioned group showed greater variability than the control group.

\section{Discussion}

The present study evaluated the role of the $\mathrm{PoS}$ in providing visual landmark control to $\mathrm{HD}$ cells in LMN. HD cells were recorded from control and PoS-lesioned rats in a cylinder across standard, cue rotation, and dark conditions, as well as in the dual-chamber apparatus where the animal walked between familiar and novel arenas. In control rats, visual landmarks dominantly controlled the preferred firing direction of HD cells. However, in PoS-lesioned rats, visual landmarks failed to reliably control HD cells, suggesting that visual landmark information is provided to HD cells in the LMN via the PoS $\rightarrow$ LMN projection. In the dual-chamber apparatus and in darkness, some HD cells of PoS-lesioned rats failed to remain stable, suggesting that, in addition to visual information, the PoS may contribute to directional perception based on selfmovement cues.

\section{Processing landmark information}

Previous studies have revealed that the HD signal is conveyed from the brainstem to higher processing regions via an ascending circuit, but no studies have indicated the point at which visual landmark information gains control of the HD signal. The ascending HD cell network includes projections from dorsal tegmental nuclei $\rightarrow \mathrm{LMN} \rightarrow \mathrm{ADN} \rightarrow \mathrm{PoS}$, and the $\mathrm{PoS}$ then projects directly to entorhinal and retrosplenial cortical areas (Fig. 8). Within the HD cell circuit, the PoS provides unique descending projections to the ADN and LMN. The PoS $\rightarrow$ ADN projection originates in the deep multiform layers V-VI, whereas the PoS $\rightarrow$ LMN projection originates in the deep layer IV pyramidal cells (using the classification scheme of Lorente de Nó, 1933), which send apical dendrites through the superficial layers (Wright et al., 2010; Yoder and Taube, 2011b). PoS layers I and III receive direct input from visual and retrosplenial cortices (Vogt and Miller, 1983; van Groen and Wyss, 1990a), which indicates that the PoS $\rightarrow$ LMN cells are in good position to receive direct visual signals that may contribute to the landmark control of HD cells. Our results indicate that landmark information gains control of the HD signal at the earliest stage within the HD circuit via the layer IV PoS $\rightarrow$ LMN pathway. Whether these layer IV PoS $\rightarrow$ LMN cells are HD cells or some other cell type that conveys visual landmark information is not known at the present time. In either case, landmark information appears to be integrated with sub- cortical self-movement cues in the LMN, and this integrated signal subsequently influences all downstream HD cell-containing structures (e.g., ADN, PoS, entorhinal cortex, retrosplenial cortex, etc.) via the ascending HD cell circuit.

In addition to its projection to LMN, the PoS may provide direct visual landmark information to many areas involved in spatial processing, including the MEC, retrosplenial cortex, perirhinal cortices, and parasubiculum, and it may provide visual landmark input indirectly to the hippocampus via the MEC. The MEC contains grid cells and HD cells, both of which are controlled by visual landmarks (Fyhn et al., 2004; Hafting et al., 2005; Sargolini et al., 2006). It is currently unknown whether PoS lesions impair landmark control in the MEC, but PoS lesions disrupt landmark control in hippocampal place cells (Calton et al., 2003), which presumably occurs through the PoS $\rightarrow$ MEC $\rightarrow$ hippocampus pathway. This finding suggests that landmark control of the MEC grid and HD cells likely arrives from the PoS. Another region that receives input from the PoS is the retrosplenial cortex, which contains HD cells and direction-specific place cells (van Groen and Wyss, 1990a; Chen et al., 1994a; Cho and Sharp, 2001). Therefore, it is possible that the PoS projections to retrosplenial cortex (both dysgranular and granular $b$ regions) carry visual landmark information, given that these regions contribute to spatial performance (van Groen et al., 2004; 
Vann and Aggleton, 2005). The PoS also projects to the perirhinal cortex (van Groen and Wyss, 1990a), which is not known to contain HD cells (Taube, 2007) and is not necessary for normal spatial learning (Aggleton et al., 1997; Burwell et al., 2004b). However, the perirhinal cortex contributes to the stability of hippocampal place cells over trials (Muir and Bilkey, 2001) and to contextual learning (Bucci et al., 2000; Bussey et al., 2000; Burwell et al., 2004a; Winters et al., 2004). An additional region that receives direct input from the PoS is the parasubiculum (van Groen and Wyss, 1990b), which contains place, HD, and grid cells that are controlled by visual landmarks (Taube, 1995b; Boccara et al., 2010). However, the PoS involvement in the landmark control of these cells has not been tested. Nonetheless, the PoS is well situated to provide visual landmark information to many of the different brain areas involved in spatial cognition.

\section{PoS contributions to spatial updating}

Evidence for the PoS playing a critical role in visual landmark processing is quite strong, but the PoS also appears to contribute to navigation in the absence of familiar visual landmarks. We note that navigation in nonvisual environments can be influenced by various sensory cues (e.g., olfactory, auditory, or tactile), and therefore, we attempted to minimize these cues in the present study. Assuming that these cues had little or no influence on HD cell stability, navigation in these conditions presumably involved the use of path integration or spatial updating. Path integration is a complex process that likely involves the integration of information from several sources (Save et al., 2001; Taube, 2007). Information about the animal's movements presumably originates in subcortical regions, such as the vestibular system, from which it is conveyed to higher brain regions involved in navigation. One such brain region is the MEC, which contains grid cells that are thought to contribute to path integration abilities (Fuhs and Touretzky, 2006; Moser et al., 2008). One source for angular path integration information arriving at the MEC is most likely the HD signal (Kubie and Fenton, 2009), which is necessary for the grid cell signal (Clark et al., 2011; Winter et al., 2014). If true, damage at any point within the ascending HD cell circuit should disrupt navigation via path integration. Consistent with this view, PoS-lesioned animals were impaired at performing a food-hoarding task in darkness, in which accurate returns depend on path integration during the outbound trip (Valerio et al., 2011). However, there is some evidence to suggest that the HD signal is not the sole source of path integration information to the MEC. Frohardt et al. (2006) reported that ADN lesions failed to markedly disrupt path integration on a food-hoarding task; impairments were present, but they were generally mild compared with lesions in other brain areas. Thus, we can conclude that the HD signal conveys angular path integration information from subcortical areas to higher brain regions, but other sources provide path integration information in some conditions. These other sources presumably contributed to the maintenance of the relatively stable preferred firing direction within each session in the lesioned animals (Fig. 4), even when accurate spatial updating by visual landmarks was impaired (Fig. $5 A, E$ ).

Angular path integration information generally arises from subcortical signals, but descending projections also appear to contribute to HD cell stability in darkness and when the animal enters a novel environment that is devoid of familiar landmarks (i.e., the dual-chamber apparatus). Some of this information appears to reach the HD cell circuit at subcortical levels via the PoS, given that PoS lesions disrupt the stability of LMN HD cells in darkness. However, many of these same HD cells remained stable in the dual-chamber apparatus, suggesting that a different source of path integration input is responsible for maintaining the $\mathrm{HD}$ signal in this task. One candidate for providing this information is the MEC, given the putative role of grid cells in path integration. However, MEC lesions failed to disrupt HD cell stability in darkness or in the dual-chamber apparatus (Clark and Taube, 2011). Another candidate is the retrosplenial cortex, which is necessary for accurate navigation on tasks that require path integration (Cooper and Mizumori, 1999; Cooper et al., 2001; Whishaw et al., 2001). However, retrosplenial cortex damage only mildly affected HD cell stability in darkness or in the dualchamber apparatus (Clark et al., 2010). A third candidate for providing path integration information to the HD signal is the hippocampus, given that hippocampal lesions disrupted ADN HD cell stability in the dual-chamber apparatus (Golob and Taube, 1999). The route by which the hippocampus influences $\mathrm{HD}$ cell stability has not been tested directly but may involve the projection from the ventral subiculum to the LMN (Shibata, 1989), given that it could not have arrived via the PoS $\rightarrow$ LMN projection in the present study. Overall, the inconsistent HD cell responses in the dual-chamber apparatus and in darkness suggest that these tasks involve different path integration mechanisms. Alternatively, PoS-lesioned rats may have been able to use the available, albeit unfamiliar, visual information to update their perceived orientation as they entered the novel rectangle of the dual-chamber apparatus. Visual information is known to improve HD cell stability in a similar task (Yoder et al., 2011a), and the present results suggest that this information does not arrive via the PoS.

\section{Conclusions}

Overall, the PoS appears to be an important component of the circuit responsible for providing landmark control to the HD signal and for providing self-movement information to higher brain structures. Landmark information is first integrated with the $\mathrm{HD}$ signal at the $\mathrm{LMN}$ via the $\mathrm{PoS} \rightarrow \mathrm{LMN}$ projection. From the $\mathrm{LMN}$, this visual information is then conveyed throughout the ascending HD cell circuit. This visual information enables HD cells throughout the HD circuit to respond similarly to landmark position. Additionally, the PoS contributes to path integration maintenance of the HD signal in situations in which familiar visual landmarks are unavailable. Therefore, the PoS is a critical component of the navigation system that is ideally situated to link the HD signal and self-movement information with entorhinal grid cells and/or hippocampal place cells, as well as to other cortical regions that contribute to navigation.

\section{References}

Aggleton JP, Keen S, Warburton EC, Bussey TJ (1997) Extensive cytotoxic lesions involving both the rhinal cortices and area TE impair recognition but spare spatial alternation in the rat. Brain Res Bull 43:279-287. CrossRef Medline

Batschelet E (1981) Circular statistics in biology. New York: Academic.

Biazoli CE Jr, Goto M, Campos AM, Canteras NS (2006) The supragenual nucleus: a putative relay station for ascending vestibular signs to head direction cells. Brain Res 1094:138-148. CrossRef Medline

Blair HT, Sharp PE (1995) Anticipatory head direction signals in anterior thalamus: evidence for a thalamocortical circuit that integrates angular head motion to compute head direction. J Neurosci 15:6260-6270. Medline

Blair HT, Lipscomb BW, Sharp PE (1997) Anticipatory time intervals of head-direction cells in the anterior thalamus of the rat: implications for path integration in the head-direction circuit. J Neurophysiol 78:145159. Medline

Blair HT, Cho J, Sharp PE (1998) Role of the lateral mammillary nucleus in 
the rat head direction circuit: a combined single unit recording and lesion study. Neuron [Erratum (1999) 22:199] 21:1387-1397. CrossRef Medline

Blair HT, Cho J, Sharp PE (1999) The anterior thalamic head-direction signal is abolished by bilateral but not unilateral lesions of the lateral mammillary nucleus. J Neurosci 19:6673-6683. Medline

Boccara CN, Sargolini F, Thoresen VH, Solstad T, Witter MP, Moser EI, Moser MB (2010) Grid cells in pre- and parasubiculum. Nat Neurosci 13:987-994. CrossRef Medline

Bucci DJ, Phillips RG, Burwell RD (2000) Contributions of postrhinal and perirhinal cortex to contextual information processing. Behav Neurosci 114:882-894. CrossRef Medline

Burwell RD, Bucci DJ, Sanborn MR, Jutras MJ (2004a) Perirhinal and postrhinal contributions to remote memory for context. J Neurosci 24: 11023-11028. CrossRef Medline

Burwell RD, Saddoris MP, Bucci DJ, Wiig KA (2004b) Corticohippocampal contributions to spatial and contextual learning. J Neurosci 24:38263836. CrossRef Medline

Bussey TJ, Duck J, Muir JL, Aggleton JP (2000) Distinct patterns of behavioural impairments resulting from fornix transection or neurotoxic lesions of the perirhinal and postrhinal cortices in the rat. Behav Brain Res 111:187-202. CrossRef Medline

Calton JL, Stackman RW, Goodridge JP, Archey WB, Dudchenko PA, Taube JS (2003) Hippocampal place cell instability after lesions of the head direction cell network. J Neurosci 23:9719-9731. Medline

Chen LL, Lin LH, Green EJ, Barnes CA, McNaughton BL (1994a) Headdirection cells in the rat posterior cortex. I. Anatomical distribution and behavioral modulation. Exp Brain Res 101:8-23. CrossRef Medline

Cho J, Sharp PE (2001) Head direction, place, and movement correlates for cells in the rat retrosplenial cortex. Behav Neurosci 115:3-25. CrossRef Medline

Clark BJ, Valerio S, Taube JS (2011) Disrupted grid and head direction cell signal in the entorhinal cortex and parasubiculum after lesions of the head direction system. Soc Neurosci Program No. 729.11.

Clark BJ, Taube JS (2011) Intact landmark control and angular path integration by head direction cells in the anterodorsal thalamus after lesions of the medial entorhinal cortex. Hippocampus 21:767-782. CrossRef Medline

Clark BJ, Bassett JP, Wang SS, Taube JS (2010) Impaired head direction cell representation in the anterodorsal thalamus after lesions of the retrosplenial cortex. J Neurosci 30:5289-5302. CrossRef Medline

Cooper BG, Mizumori SJ (1999) Retrosplenial cortex inactivation selectively impairs navigation in darkness. Neuroreport 10:625-630. CrossRef Medline

Cooper BG, Manka TF, Mizumori SJ (2001) Finding your way in the dark: the retrosplenial cortex contributes to spatial memory and navigation without visual cues. Behav Neurosci 115:1012-1028. CrossRef Medline

Frohardt RJ, Bassett JP, Taube JS (2006) Path integration and lesions within the head direction cell circuit: comparison between the roles of the anterodorsal thalamus and dorsal tegmental nucleus. Behav Neurosci 120: 135-149. CrossRef Medline

Fuhs MC, Touretzky DS (2006) A spin glass model of path integration in rat medial entorhinal cortex. J Neurosci 26:4266-4276. CrossRef Medline

Fyhn M, Molden S, Witter MP, Moser EI, Moser MB (2004) Spatial representation in the entorhinal cortex. Science 305:1258-1264. CrossRef Medline

Gallistel CR (1990) The organization of learning. Cambridge, MA: Massachusetts Institute of Technology.

Golob EJ, Taube JS (1997) Head direction cells and episodic spatial information in rats without a hippocampus. Proc Natl Acad Sci U S A 94:76457650. CrossRef Medline

Golob EJ, Taube JS (1999) Head direction cells in rats with hippocampal or overlying neocortical lesions: evidence for impaired angular path integration. J Neurosci 19:7198-7211. Medline

Goodridge JP, Taube JS (1995) Preferential use of the landmark navigational system by head direction cells in rats. Behav Neurosci 109:49-61. CrossRef Medline

Goodridge JP, Taube JS (1997) Interaction between the postsubiculum and anterior thalamus in the generation of head direction cell activity. J Neurosci 17:9315-9330. Medline

Goodridge JP, Dudchenko PA, Worboys KA, Golob EJ, Taube JS (1998) Cue control and head direction cells. Behav Neurosci 112:749-761. CrossRef Medline
Hafting T, Fyhn M, Molden S, Moser MB, Moser EI (2005) Microstructure of a spatial map in the entorhinal cortex. Nature 436:801-806. CrossRef Medline

Kjonigsen LJ, Leergaard TB, Witter MP, Bjaalie JG (2011) Digital atlas of anatomical subdivisions and boundaries of the rat hippocampal region. Front Neuroinform 5:2. CrossRef Medline

Knierim JJ, Kudrimoti HS, McNaughton BL (1995) Place cells, head direction cells, and the learning of landmark stability. J Neurosci 15:1648 1659. Medline

Kubie JL (1984) A driveable bundle of microwires for collecting single-unit data from freely-moving rats. Physiol Behav 32:115-118. CrossRef Medline

Kubie JL, Fenton AA (2009) Heading-vector navigation based on headdirection cells and path integration. Hippocampus 19:456-479. CrossRef Medline

Lorente de Nó R (1933) Studies on the structure of the cerebral cortex I. the area entorhinalis. J Psychol Neurol 45:381-438.

Mardia KV (1972) Statistics of directional data. New York: Academic.

Moser EI, Kropff E, Moser MB (2008) Place cells, grid cells, and the brain's spatial representation system. Annu Rev Neurosci 31:69-89. CrossRef Medline

Muir GM, Bilkey DK (2001) Instability in the place field location of hippocampal place cells after lesions centered on the perirhinal cortex. J Neurosci 21:4016-4025. Medline

Paxinos G, Watson C (1998) The rat brain in stereotaxic coordinates, Ed 4. San Diego: Academic

Sargolini F, Fyhn M, Hafting T, McNaughton BL, Witter MP, Moser MB, Moser EI (2006) Conjunctive representation of position, direction, and velocity in entorhinal cortex. Science 312:758-762. CrossRef Medline

Save E, Guazzelli A, Poucet B (2001) Dissociation of the effects of bilateral lesions of the dorsal hippocampus and parietal cortex on path integration in the rat. Behav Neurosci 115:1212-1223. CrossRef Medline

Shibata H (1989) Descending projections to the mammillary nuclei in the rat, as studied by retrograde and anterograde transport of wheat germ agglutinin-horseradish peroxidase. J Comp Neurol 285:436-452. CrossRef Medline

Shibata H (1993) Direct projections from the anterior thalamic nuclei to the retrohippocampal region in the rat. J Comp Neurol 337:431-445. CrossRef Medline

Song P, Wang XJ (2005) Angular path integration by moving "hill of activity": a spiking neuron model without recurrent excitation of the headdirection system. J Neurosci 25:1002-1014. CrossRef Medline

Stackman RW, Taube JS (1997) Firing properties of head direction cells in the rat anterior thalamic nucleus: dependence on vestibular input. J Neurosci 17:4349-4358. Medline

Stackman RW, Taube JS (1998) Firing properties of rat lateral mammillary single units: head direction, head pitch, and angular head velocity. J Neurosci 18:9020-9037. Medline

Taube JS (1995a) Head direction cells recorded in the anterior thalamic nuclei of freely moving rats. J Neurosci 15:70-86. Medline

Taube JS (1995b) Place cells recorded in the parasubiculum of freely moving rats. Hippocampus 5:569-583. CrossRef Medline

Taube JS (2007) The head direction signal: origins and sensory-motor integration. Annu Rev Neurosci 30:181-207. CrossRef Medline

Taube JS, Bassett JP (2003) Persistent neural activity in head direction cells. Cereb Cortex 13:1162-1172. CrossRef Medline

Taube JS, Burton HL (1995) Head direction cell activity monitored in a novel environment and during a cue conflict situation. J Neurophysiol 74:1953-1971. Medline

Taube JS, Muller RU, Ranck JB Jr (1990a) Head-direction cells recorded from the postsubiculum in freely moving rats. I. Description and quantitative analysis. J Neurosci 10:420-435. Medline

Taube JS, Muller RU, Ranck JB Jr (1990b) Head-direction cells recorded from the postsubiculum in freely moving rats. II. Effects of environmental manipulations. J Neurosci 10:436-447. Medline

Valerio S, Clark BJ, Yoder RM, Taube JS (2011) Lesions of the postsubiculum disrupt path integration. Soc Neuroci Abstr 37:729.21.

van Groen T, Wyss JM (1990a) The postsubicular cortex in the rat: characterization of the fourth region of the subicular cortex and its connections. Brain Res 529:165-177. CrossRef Medline

van Groen T, Wyss JM (1990b) The connections of the presubiculum and parasubiculum in the rat. Brain Res 518:227-243. CrossRef Medline 
van Groen T, Wyss JM (1995) Projections from the anterodorsal and anteroventral nucleus of the thalamus to the limbic cortex in the rat. J Comp Neurol 358:584-604. CrossRef Medline

van Groen T, Kadish I, Wyss JM (2004) Retrosplenial cortex lesions of area $\mathrm{Rgb}$ (but not of area Rga) impair spatial learning and memory in the rat. Behav Brain Res 154:483-491. CrossRef Medline

Vann SD, Aggleton JP (2005) Selective dysgranular retrosplenial cortex lesions in rats disrupt allocentric performance of the radial-arm maze task. Behav Neurosci 119:1682-1686. CrossRef Medline

Vogt BA, Miller MW (1983) Cortical connections between rat cingulate cortex and visual, motor, and postsubicular cortices. J Comp Neurol 216: 192-210. CrossRef Medline

Whishaw IQ, Hines DJ, Wallace DG (2001) Dead reckoning (path integration) requires the hippocampal formation: evidence from spontaneous exploration and spatial learning tasks in light (allothetic) and dark (idiothetic) tests. Behav Brain Res 127:49-69. CrossRef Medline

Winter SS, Clark BJ, Taube JS (2014) Anterior thalamus inactivation disrupts grid cell firing in the entorhinal cortex. Soc Neurosci Program No. 94.29.

Winters BD, Forwood SE, Cowell RA, Saksida LM, Bussey TJ (2004) Double dissociation between the effects of peri-postrhinal cortex and hippocampal lesions on tests of object recognition and spatial memory: heterogeneity of function within the temporal lobe. J Neurosci 24:5901-5908. CrossRef Medline

Wright NF, Erichsen JT, Vann SD, O’Mara SM, Aggleton JP (2010) Parallel but separate inputs from limbic cortices to the mammillary bodies and anterior thalamic nuclei in the rat. J Comp Neurol 518:2334-2354. CrossRef Medline

Yoder RM, Taube JS (2009) Head direction cell activity in mice: robust directional signal depends on intact otolith organs. J Neurosci 29:10611076. CrossRef Medline

Yoder RM, Clark BJ, Brown JE, Lamia MV, Valerio S, Shinder ME, Taube JS (2011a) Both visual and idiothetic cues contribute to head direction cell stability during navigation along complex routes. J Neurophysiol 105: 2989-3001. CrossRef Medline

Yoder RM, Taube JS (2011b) Projections to the anterodorsal thalamus and lateral mammillary nuclei arise from different cell populations within the postsubiculum: Implications for the control of head direction cells. Hippocampus 21:1062-1073. CrossRef Medline

Yoganarasimha D, Yu X, Knierim JJ (2006) Head direction cell representations maintain internal coherence during conflicting proximal and distal cue rotations: comparison with hippocampal place cells. J Neurosci 26: 622-631. CrossRef Medline

Zhang K (1996) Representation of spatial orientation by the intrinsic dynamics of the head-direction cell ensemble: a theory. J Neurosci 16:21122126. Medline

Zugaro MB, Arleo A, Berthoz A, Wiener SI (2003) Rapid spatial reorientation and head direction cells. J Neurosci 23:3478-3482. Medline 